\title{
Effect of Fungal Endophytes on Plant Growth and Nutrient Uptake in Trifolium Subterraneum and Poa Pratensis as Affected by Plant Host Specificity
}

\author{
Carlos García-Latorre \\ University of Extremadura: Universidad de Extremadura \\ Sara Rodrigo \\ University of Extremadura: Universidad de Extremadura \\ Oscar Santamaria (D osantama@usal.es) \\ University of Salamanca: Universidad de Salamanca
}

\section{Research Article}

Keywords: Endophytic fungi, Subterranean clover, Kentucky Bluegrass, nutrient uptake, plant growth promoters, endophyte-host interaction

Posted Date: July 1st, 2021

DOI: https://doi.org/10.21203/rs.3.rs-432832/v2

License: @ (1) This work is licensed under a Creative Commons Attribution 4.0 International License. Read Full License

Version of Record: A version of this preprint was published at Mycological Progress on September 1st, 2021. See the published version at https://doi.org/10.1007/s11557-021-01732-6. 


\section{Abstract}

The introduction of well-adapted species, such as Trifolium subterraneum and Poa pratensis, might enhance the forage yield and quality of dehesas pastures for feeding livestock. However, the climatic hardness and poor soils in these agrosystems may limit plant establishment and development. Since fungal endophytes have been found to alleviate the environmental stresses of their host, the aim of this study was to assess the effect of five isolates on forage yield, nutritive value and plant mineral uptake after their inoculation in the two above-mentioned plant species. Two experiments were established (under greenhouse and field conditions) using plants inoculated with two isolates in 2012/2013 (Epicoccum nigrum, Sporormiella intermedia) and three isolates in 2013/2014 (Mucor hiemalis, Fusarium equiseti, Byssochlamys spectabilis). Thus, F. equiseti (E346) increased the herbage yield of $T$. subterraneum under greenhouse conditions, B. spectabilis was found to improve the forage quality of $T$. subterraneum by reducing fibre content and of $P$. pratensis by increasing crude protein. Also, $S$. intermedia increased the mineral uptake of $\mathrm{Ca}, \mathrm{Cu}, \mathrm{Mn}, \mathrm{Pb}, \mathrm{Tl}$ and $\mathrm{Zn}$ in subclover and $\mathrm{M}$. hiemalis, the uptake of $\mathrm{K}$ and $\mathrm{Sr}$ in Kentucky bluegrass. These results evidenced the potential of the studied fungal endophytes to enhance herbage yield and the forage nutritional value, although further studies should include all of the intended forage species as certain host specificity in the effect was observed.

\section{Introduction}

Dehesas are Mediterranean agrosilvopastoral systems located mainly in the southwest of the Iberian Peninsula, characterized by a steadiness between production and conservation (Moreno and Pulido 2009; Simón et al. 2013). Extensive livestock grazing is usually the main activity and it plays a key role in the system by increasing the forage yield and biodiversity of pastures (Pinto-Correia et al. 2011; López-Sánchez et al. 2016). However, the productivity of dehesas is frequently limited due to the climate harshness and the low quality of the soil (Olea and San Miguel-Ayanz 2006; Schnabel et al. 2013).

In this context, forage provided by natural grasslands may not be enough to satisfy the nutritional requirements of livestock in terms of quantity and quality. Under these conditions, the introduction (or, at least, the enhancement) of well-adapted species that can increase the forage yield and improve the nutritive value of the herbage, might be a good strategy to cope with, or leastwise alleviate, this feeding deficiency. Traditionally these introductions have been performed by using forage species of grasses and/or leguminous crops, such as Kentucky bluegrass (Poa pratensis L.) and subterranean clover (Trifolium subterraneum L.), respectively. Kentucky bluegrass, a perennial pasture grass in Europe, is a very palatable and high-yielding plant, able to produce 4,100 to $10,400 \mathrm{~kg} \mathrm{DM} \mathrm{ha}^{-1}$, depending on the environment, especially rainfall (Dürr et al. 2005; Bender et al. 2006). On the other hand, subterranean clover, also called subclover, as naturally present in this ecosystem, is one of the key species due to its high quality and late senescence in the growing season (San Miguel 1994). For this reason, it is one of the most important legumes used in sown pastures in countries with temperate or Mediterranean climates, like Spain (Frame et al. 1998). Moreover, subterranean clover is often used for the recovery of degraded pastures, to increase the forage yield and prevent soil erosion (Crespo and Cordero 1998).

Although these two species present a certain hardiness which allows them to grow in the harsh climatic conditions and low soil fertility of this ecosystem, their establishment and performance might be limited, decreasing then their vegetative growth, forage yield and the nutritive content of their herbage (Bolger et al. 1993; Croce et al. 2001; Hodge 2004). However, plants are not isolated organisms, as they establish mutualistic or symbiotic relationships with other living forms such as fungi or bacteria which allow them to improve their performance under unfavourable conditions. Therefore, the utilization of such organisms could be a good strategy to enhance their development under the semiarid conditions of dehesas. Within those associations, fungal endophytes are organisms that may spend their life cycle inside the host plant tissues without causing symptoms of disease (Rodriguez et al. 2009). These fungi can confer adaptive advantages to host plants by improving their stress tolerance or protecting them against grazing, pests and diseases, resulting in a better plant growth and consequently in higher herbage yield (Ismail et al. 2018). Fungal endophytes have been proved to increase water and nutrient uptake by plant hosts (Schardl et al. 2008), as well as to enhance plant resistance against biotic and abiotic stresses, such as salt accumulation and drought (Moghaddam et al. 2021; Zhou et al. 2021). The capacity of endophytes to induce the increase of mineral uptake by host plants (García-Latorre et al. 2021) has also been used for the detoxification of contaminated soils with heavy metals like Ni (Wazny et al. 2021).

Endophytic fungi have also been reported to produce phytohormone-like substances, particularly gibberellins (GAs) and indole-3-acetic acid (IAA) that can both, enhance plant vegetative growth and help plant hosts to protect them against the harmful effects of abiotic stresses (Waqas et al. 2014; Ismail et al. 2021). Thus, the possibility of using these phytohormone-like substances produced by endophytes as plant growth promoters may lead to a more sustainable and environmentally friendly agriculture. Furthermore, under a climate change scenario, where a decrease in rainfall is expected in Mediterranean areas (Bilal et al. 2018), the use of these endophytes or their metabolites may contribute to mitigate its effects by maintaining an acceptable level of forage yield with a lower precipitation, as well as reducing the use of synthetic chemical fertilizers. 
Correctly evaluated, the optimization of the plant-endophyte interaction may become an important pathway to increase productivity, since these effects could be obtained in a wide variety of plant species (Rodriguez et al. 2008; Redman et al. 2011). However, the effect of an endophyte on a particular plant host may be variable (Bastías et al. 2021) depending on the endophytic species, the host genotype and environmental conditions (Ahlholm et al. 2002). Consequently, it should be conveniently outlined the particular outcomes of the association between specific fungal symbionts and plants in order to get the widest range of application. This would be particularly important in natural grasslands, such as dehesas, and other polyculture systems, where the specific variability of plants is quite high, and where not very closely related species, such as grasses and leguminous species, co-occur.

Several studies concerning the effect of endophytes on a single pasture host under the same environmental conditions have already been conducted in Poa pratensis (Lledó et al. 2015), Trifolium subterraneum (Lledó et al. 2016a) and another legume species such as Ornithopus compressus (Santamaria et al. 2017), but they were carried out with a different set of fungal endophytes and the effect of the host was not considered. Therefore, in order to find a wider number of fungal endophytes with positive effects on the general performance of plant hosts and at the same time to evaluate the specificity of these eventual effects, the objective of the present study was to assess the effect of the artificial inoculation with each of five different species of non-clavicipitaceous endophytes on the forage yield (herbage and root biomass), quality traits and nutrient uptake in two important and not very taxonomically related forage crops, such as a leguminous species (Trifolium subterraneum) and a gramineous species (Poa pratensis).

\section{Material And Methods}

\section{Fungal and plant material}

For the inoculations, five fungal endophytes (Table 1), previously isolated from different pastures species of dehesas from Extremadura (Southwest of Spain), were selected either, because they had been quite frequently isolated from several pasture hosts, a fact which could reflect an eventual important ecological role, or based on the observation of some interesting properties related to plant protection in previous experiments carried out in our laboratory, such as antagonism against fungal pathogens or the production of several secondary metabolites (data not shown). These endophytes had been previously identified by morphological characteristics, when possible, and by the comparison of the ITS region sequence with sequences from EMBL/GenBank (www.NCBI.nIm.nih.gov) and UNITE (https://unite.ut.ee. Version 8.3; Kõljalg et al. 2020) databases using a BLAST search. A more detailed explanation about how the species assignation was made when multiple accessions or ambiguous results were found, and other aspects about identification, can be obtained from Lledó et al. (2016b) and Santamaria et al. (2018).

The experiments were carried out over 2 years, in 2012/2013 with two of the endophytes: E179 (Epicoccum nigrum) and E636 (Sporormiella intermedia), and in 2013/2014 with the rest of the endophytes: E063 (Mucor hiemalis), E346 (Fusarium equiseti) and E408 (Byssochlamys spectabilis). In both study years, in order to obtain enough inoculum for the plant inoculations, active mycelium from each fungus was grown at $25^{\circ} \mathrm{C}$ in $1.5 \mathrm{~L}$ flasks containing $1 \mathrm{~L}$ of Potato Dextrose Broth (PDB). The flasks were kept in the dark during two months before the inoculation, being shaken manually for 5 minutes every 3 days.

Inoculations were carried out in two-month old seedlings of T. subterraneum cv 'Valmoreno' and P. pratensis cv 'Sobra'. In order to obtain the plant seedlings, seeds of each species were first surface disinfected by immersion for 5 and 2 minutes respectively in $2.5 \%$ NaClO, followed by three washes with sterilized distilled water. Five individual surface sterilized seeds per plant species ( $\mathrm{N}=10$ total samples) were randomly selected and imprinted onto fresh potato dextrose agar (PDA, Scharlau, Spain) as a way to verify the surface sterilization efficiency, and no outgrowing fungal colonies were observed. After that, five sterilized seeds per pot for $T$. subterraneum and ten seeds for $P$. pratensis were sown in $7 \times 7 \times 6 \mathrm{~cm}$ plastic pots containing autoclaved (twice during 1 hour at $121^{\circ} \mathrm{C}$ ) soil substrate consisting of a $1: 1$ (vol/vol) mix of perlite and a commercial growing medium composed of peat, perlite, lime, root activator and fertilizer NPK (COMPO SANA Universal, COMPO GmbH \& Co. KG, Münster Germany). The substrate characteristics (Table 2) were calculated on four homogenized samples as follows: Electrical conductivity (EC) was determined using an EC-meter and pH, using a calibrated pH meter (ratio $10 \mathrm{~g}$ soil: $25 \mathrm{ml}$ deionized $\mathrm{H} 2 \mathrm{O}$ ). Total $\mathrm{N}$ was determined using the Kjeldahl method (Bremner 1996), by means of a Kjeltec ${ }^{\mathrm{TM}} \mathrm{K} 350$ distillation Unit (Buchi Ltd., Flawil, Switzerland).

Extractable $\mathrm{P}$ was determined by the Olsen procedure, and $\mathrm{Ca}$ and $\mathrm{K}$ were extracted with ammonium acetate (1 N) and quantified by atomic absorption spectrophotometry (Helyos alpha, 9423-UVA, Unicam, Cambridge, UK). Total Al, B, Ca, Cu, Fe, K, Li, Mg, Mn, Mo, Na, P, Pb, S, Se and Zn concentrations were determined by the lonomics Service of CSIC (Spanish High Centre for Science and Research) by means of inductively coupled plasma optical emission spectrometry (ICP-OES). An approximation to the normal range of each nutrient in soils for the pasture growth is also shown in Table 2. In general, values were within range, and when this was not the case, the values were not considered sufficient to cause toxicity in the plant (Reid and Dirou 2004; Hazelton and Murphy 2016). 
The sowing date was in early December in both study years. After that, pots were placed in a greenhouse and watered to field capacity every 2 to 3 days. Environmental conditions in the greenhouse, such as maximum and minimum temperatures and relative humidity, were monitored throughout the entire length of the experiment (Fig. 1).

Before the endophyte inoculation, plants were treated three times with a systemic fungicide, Amistar Xtra ${ }^{\circledR}(20 \mathrm{~g}$ of $A$ zoxystrobin and $8 \mathrm{~g}$ of cyproconazole each $5 \mathrm{~L}$; Syngenta, Madrid, Spain). The aim of this treatment was to remove any pre-existing fungus within the plant that could limit the colonization of our selected strains or interact somehow with them, altering the results. Thus, the first treatment was made when plants were 1 month old, and then again, every 10 days as a foliar spray (approx. $1 \mathrm{~mL}$ per pot of a dilution of $1 \mathrm{~mL}$ fungicide in $1 \mathrm{~L}$ distilled water). With the third application, $1 \mathrm{~mL}$ of fungicide solution was also added to the soil substrate in each pot. The effectiveness of the fungicide treatment was evaluated just before inoculations by taking randomly four plants and analysed in the laboratory. Five mm-long

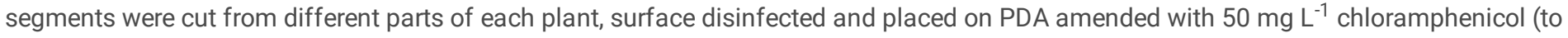
avoid bacteria development) in a Petri dish. After two months of incubation at $25^{\circ} \mathrm{C}$ in the dark, no colonies of fungi were observed growing out of any of the plant segments.

\section{Inoculations}

Inoculations were performed five weeks after the last fungicide application. Just before inoculations, plants were wounded by using a homemade tool that allowed puncturing their leaves and stems to facilitate fungal infection without serious plant damage. Then, a homogenized blended mix of inoculum was applied by means of a hand sprayer to all the plants in two doses: one dose just after plant wounding, and the second one 3 days later. Then the inoculated seedlings were maintained in a high humidity atmosphere during the $48 \mathrm{~h}$ after the application in order to favour infections. The viability of the mycelium after blending was evaluated in vitro, by verifying the growth of new colonies on Petri dishes containing PDA sprayed with the blended mix. Ten pots or experimental units (containing five plants each in the case of $T$. subterraneum and 10 plants in the case of $P$. pratensis) were inoculated with each of the endophytes. Ten additional pots or experimental units were inoculated only with culture medium to be used as control. Each plant received a different amount of mycelia depending on the endophytic species inoculated due to their different growth rate: E063 (M. hiemalis) 74.0 mg plant $^{-1}$, E179 (E. nigrum) 274 mg plant $^{-1}$, E346 ( $F$. equiseti) $134.0 \mathrm{mg} \mathrm{plant}^{-1}$, E408 (B. spectabilis) $63.8 \mathrm{mg} \mathrm{plant}^{-1}$ and E636 (S. intermedia) $282.6 \mathrm{mg} \mathrm{plant}^{-1}$.

In order to check the effectiveness of the inoculations, approximately 1 month after the inoculations, plant samples of each treatment were taken to the laboratory for re-isolation, which was performed by using the same procedure followed to evaluate the effectiveness of the systemic fungicide described above. After the re-isolation process, the five endophytes were positively re-isolated and identified in culture medium. This might mean that the inoculation method was sufficiently effective to cause infection, and consequently the differences observed between treatments could be attributed to the inoculation.

Each year, one half of the pots containing inoculated plants were kept in the greenhouse (i.e. a total of 60 pots for each plant host), arranged on benches by following a completely randomized design, separated at least $5 \mathrm{~cm}$ apart to avoid cross-contamination. Plants were watered to field capacity every 2 to 3 days. In order to evaluate eventual pathogenic behaviour of the endophytes used in the present study on the studied hosts, these plants were visually examined five times every three weeks (starting three weeks after inoculation) to check for disease symptoms (yellowing, drying, rotting leaves, blackish spots, etc.). According to the severity of these symptoms, on average the plants in each pot were assigned to one category on the following scale: $1=$ healthy, $2=$ slightly affected, $3=$ moderately affected, $4=$ severely affected and $5=$ dead. Disease progress curves for each pot were constructed by plotting the values of disease severity over time. The area under the disease progress curve (AUDPC) was calculated as the sum of the area of the corresponding trapezoids, considering one unit per period between two consecutive measurements. The AUDPC was used as response variable to evaluate disease severity. Three months after inoculations, herbage and roots were harvested and taken to the laboratory for processing.

To evaluate the consistency of the eventual effects caused by the endophytes on the host plants, as they have been shown to be dependent on the environmental conditions [1], the second half of the pots (the remaining five repetitions) were transported to the field approximately one month after the inoculations. In 2012/2013, only plants of $T$. subterraneum could be transplanted in the field, while in $2013 / 2014$, plants of both species were used for this part of the assay. In both years, the experimental area was in the Dehesa Valdesequera, owned by the regional government of Extremadura and located in Badajoz, south-west Spain (UTM Coordinates, Zone 29 North Datum: X=685,365 m; $\mathrm{Y}=4,325,603$ ). Four soil samples 30 -cm depth of the experimental area were taken to the laboratory to determine their properties by using the same procedures followed for the substrate. The values can be observed in Table 2. Climatic data during the experiment, which were taken from a weather station located close to the study site, are shown in Fig. 1. Before transplanting, in late February of each year, conventional tillage was applied to prepare an appropriate environment for plants. The experimental units (a set of five plants) were arranged by using a randomized design with a planting layout of $50 \mathrm{~cm} \times 50 \mathrm{~cm}$. After transplanting, seedlings were maintained without further fertilization or irrigation. Two months and a half after transplanting, herbage was harvested and taken to the laboratory for processing.

Page 4/19 


\section{Yield and quality determinations}

After harvesting, plant samples were oven dried at $70^{\circ} \mathrm{C}$ until constant weight for dry matter (DM) of herbage and root biomass (from greenhouse) determination. The dried samples, after grinding, were also used to determine the main quality parameters. Thus, total $\mathrm{N}$ content was analysed by the Kjeldahl method (Kjeltec ${ }^{\mathrm{TM}} 8200$ Auto Distillation Unit. FOSS Analytical. Hilleroed, Denmark) and used to estimate crude protein (CP) by multiplying the biomass $\mathrm{N}$ by 6.25 (Sosulski and Imafidon, 1990). Official procedures (AOCS 2006) were followed to determine neutral detergent fibre (NDF), acid detergent fibre (ADF), and acid detergent lignin (ADL) by means of a fibre analyzer (ANKOM8- 98, ANKOM Technology, Macedon, NY). Total ash content was determined by ignition of the sample in a muffle furnace at $600{ }^{\circ} \mathrm{C}$, according to the official procedure (AOCS 2006). An aliquot of each sample was sent to the lonomics Service of CSIC (Spanish High Centre for Science and Research) for mineral determinations with an ICP-OES as explained for the soil samples. The mineral content was determined in $2012 / 2013$ for both greenhouse and field samples but only for the field samples in 2013/2014.

\section{Statistical analysis}

The effect of the endophyte inoculation (three treatments, including controls in 2012/2013, and four treatments, including controls in 2013/2014), plant host (Trifolium subterraneum and Poa pratensis), and their interaction, was evaluated on disease severity (estimated as the area under the disease progress curve, AUDCP), herbage dry matter (HDM and FDM for the greenhouse and field experiment respectively), root dry matter (RDM; only in the greenhouse experiment), nutritive value parameters (CP, NDF, ADF, and ADL) and mineral concentration by means of two-way ANOVAs. A Fisher's protected least significant difference (LSD) test for multiple comparison was used when significant differences $(P<0.05)$ were found in the ANOVA. In order to normalize the variable distribution as well as to stabilize the variance of residues, the transformation $\sqrt[5]{ } \mathrm{x}$ was performed for Herbage Dry Matter (HDM), Root Dry Matter (RDM) and Neutral Detergent Fibre (NDF). For the NDF, the transformation was applied in both field and greenhouse values. In any case, untransformed values for these three parameters are shown in tables and figures, for clarification. The rest of variables were analysed using the original data. All the analyses were performed with the Statistix v. 8.10 package (Analitical Software, USA).

\section{Results}

\section{Effects of endophytes on disease severity, biomass yield, quality parameters and mineral content in the greenhouse experiment}

Although the area under the disease progress curve (AUDCP) was significantly affected by the endophyte treatment in 2012/2013 (Table 3), none of the endophytes caused a higher disease severity in comparison with controls. Conversely, plants inoculated with the endophyte E179 (Epicoccum nigrum) showed healthier values than those observed in controls (mean values \pm standard error [ $n=10$ ]: $6.00 \pm 0.42$ for E636, $5.75 \pm 0.27$ for controls and $4.95 \pm 0.13$ for E179). Regarding biomass yield, even when in both study years the inoculation with an endophyte significantly affected the herbage dry matter (HDM; Table 3), in 2012/2013 such an effect depended on the plant host, as their interaction was also significant $(P<0.05)$. Considering the endophyte inoculation as main effect, both HDM and RDM (root dry matter) were not increased by any of the endophytes in both study years in comparison with the non-inoculated plants. Conversely, the plants inoculated with endophyte E408 showed a significant decrement in the biomass yield (in both HDM and RDM) in 2013/2014 in relation with controls (Fig. 2a) of about $11 \%$ and $14 \%$, respectively.

When the interaction 'inoculated endophyte*host' was analysed (Fig. 2b), significant differences $(P \leq 0.05)$ in the herbage and root biomass yield of the host caused by the inoculation were only found on Trifolium subterraneum. In 2012/2013 for that host, in relation to HDM, such differences were negative, as the inoculation with endophyte E636 caused a decrease of around 36\% in the herbage dry matter in comparison with control plants (Fig. 2b). During 2013/2014, however, the inoculation of subclover with E346 did increase the herbage biomass with respect to their control. In relation to RDM, the inoculation with endophyte E179 increased the root biomass yield in plants of $T$. subterraneum when comparing with non-inoculated plants (Fig. 2b).

In general, the influence of the endophyte inoculation on the nutritional quality traits was quite limited. In 2012/2013 a significant influence of the endophyte, in terms of either main effect or the interaction with the host, was only found for the acid detergent fibre (ADF) and the ash content in the herbage, respectively (Table 3). In such a case, the endophyte E636 caused a decrease of $9.3 \%$ in the ADF percentage in comparison with control (Fig. 3c). Regarding the ash content, the inoculation with either, endophyte E179 or E636, produced plants with significantly lower values for Trifolium subterraneum, 0.26 and $0.27 \%$ respectively, in comparison with controls, which accounted $0.43 \%$. No differences were observed for Poa pratensis for this parameter. In 2013/2014, the interaction between the endophyte inoculation and the plant 
host species affected significantly the neutral detergent fibre (NDF). Thus, the inoculation with E408 (B. spectabilis) caused a decrement of a $10 \%$ in the plants of Trifolium subterraneum with respect to the uninoculated ones (Fig. $3 \mathrm{~b}$ ).

Regarding the nutrient uptake, only the main significant effects of the endophyte inoculation on the concentration of minerals in herbage are shown in Table 4 (the whole set of results can be found in Appendix A, Table S1). Thus, results in the greenhouse showed that the fungal inoculation affected the plant uptake of $\mathrm{Ca}, \mathrm{Cr}, \mathrm{Mo}, \mathrm{Na}, \mathrm{Pb}$ and $\mathrm{Tl}$, when considered as main effect, and $\mathrm{Ca}, \mathrm{Cr}, \mathrm{Cu}, \mathrm{Mn}, \mathrm{Na}, \mathrm{P}, \mathrm{Pb}, \mathrm{S}, \mathrm{Ti}, \mathrm{TI}$ and $\mathrm{Zn}$, when considering its interaction with the plant host. The inoculation with Sporormiella intermedia (E636) caused a significant increase in the uptake of $\mathrm{Ca}, \mathrm{Cu}, \mathrm{Mn}, \mathrm{Pb}, \mathrm{Tl}$ and $\mathrm{Zn}$ by the plants of $\mathrm{T}$. subterraneum and a decrease in the uptake of $\mathrm{Cr}$ in this same host plants (Table 4). On the other hand, the inoculation with Epiccocum nigrum (E179) decreased significantly the uptake (down to 3.8 times) of Ti by plants of $T$. subterraneum. The inoculation with both endophytes caused a decrease in the uptake of $\mathrm{Cr}(-57.30 \%$ for E179 and $-73.94 \%$ for E636) and S (-40.46\% and $-37.40 \%$ respectively) in plants of $P$. pratensis (Appendix A).

\section{Effects of endophytes on biomass yield, quality parameters and mineral content in the field experiment}

Results from the field experiment showed no significant effect of the endophyte inoculation in the herbage yield in any of the years (Table 2). Field dry matter (FDM) for T. subterraneum ranged from $4.18 \mathrm{~g} \mathrm{unit}^{-1}$ in the control to $5.23 \mathrm{~g}_{\text {unit }}{ }^{-1}$ when E179 was inoculated in $2012 / 2013$, and from $15.72 \mathrm{~g} \mathrm{unit}^{-1}$ to $17.88 \mathrm{~g} \mathrm{unit}^{-1}$ when E179 and E346 were inoculated in 2013/2014, respectively. In the case of Poa pratensis, FDM ranged from $1.59 \mathrm{~g} \mathrm{unit}^{-1}$ to $2.27 \mathrm{~g} \mathrm{unit}^{-1}$ when E346 and E408 were inoculated in 2013/2014 (Fig. 1a).

Regarding the influence on the quality traits, the fungal inoculation, as main effect, affected significantly $(P<0.05)$ ADF and ADL in the first year (2013/2014). The crude protein (CP) was also affected by the fungal inoculation in 2013/2014, but only considering the interaction with the host. In 2012/2013, the inoculation with E636 increased the ADF content of the herbage by around a 15\% and the ADL by around a $79.06 \%$ with respect to the control (Fig. 3c; 3d). On the other hand, in 2013/2014, when the interaction 'inoculated endophyte*plant host' was analysed, it was observed that the inoculation with the endophyte E346 (Fusarium equiseti) caused a decrease in the protein content from $17.75 \%$ to $15.70 \%$, but only in T. subterraneum. The same effect was observed when Byssochlamys spectabilis (E408) was inoculated in the same host, although such a response was completely opposite when it was inoculated in $P$. pratensis, increasing the crude protein content around a $9 \%$ (Fig. 3a).

As in the greenhouse experiment description, in relation to the influence of the endophyte inoculation on the mineral accumulation in herbage, here also the main significant effects are only shown in this case in Table 5 (the whole set of results can be found in Appendix A, Table S2). In $2012 / 2013$, the uptake of Cu, P, TI and Zn by T. subterraneum (only species in the field experiment during that year) was significantly affected by the inoculation with the endophyte E636, causing a lower uptake of $\mathrm{P}(-33.33 \%)$ and $\mathrm{Zn}(-23.51 \%)$ but increasing the uptake of $\mathrm{TI}$ in a $45 \%$ (Appendix A; Table S2). In 2013/2014, the uptake of B, Cu, Na, S and Zn was significantly affected by the endophyte inoculation when it was considered as main effect (Table 5), and the uptake of $\mathrm{B}, \mathrm{Cr}, \mathrm{K}, \mathrm{Mg}$ and Sr was affected by the interaction 'inoculated endophyte* plant host'. The inoculation with E063 increased the uptake of B (+14.79\%) and $\mathrm{Na}(+20.69 \%)$ on average, while plants inoculated with E408 presented higher concentrations of $\mathrm{B}, \mathrm{Cu}, \mathrm{Na}, \mathrm{S}$ and $\mathrm{Zn}$, by a $13.29 \%, 14.11 \%, 10.34 \%, 14.29 \%$ and $17.68 \%$, respectively.

Considering the interaction 'inoculated endophyte*plant host', the uptake of B was significantly increased by the inoculation with E063 (+26.73\%) and E408 (+19.74\%) only in T. subterraneum (Table 5). The inoculation with E063 also increased the Trifolium uptake of Cr by a $75 \%$, while the inoculation with E408 caused an increase in the uptake of $\mathrm{Cr}, \mathrm{K}, \mathrm{Mg}$ and $\mathrm{Sr}(33.71 \%, 12 \%, 16.67 \%$ and $18.82 \%)$ in $P$. pratensis. Finally, plants of Poa pratensis inoculated with E346 presented a higher concentration of K (+10\%) and $\mathrm{Sr}(+18.82 \%)$ in relation with controls (Table 5).

\section{Discussion}

The effectiveness of the artificial inoculations was confirmed by the fact that the five fungi used were successfully re-isolated from the inner tissues of host plants. Therefore, it may be reasonable to suggest that the selected endophytes colonized the internal tissues of both pasture species, T. subterraneum and $P$. pratensis, and consequently the different effects found on the parameters analysed after inoculations could be mainly attributed to the endophyte inoculated. In addition, no other colony was re-isolated from any of the plant samples after the fungicide application. Consequently, the influence of the naturally occurring microbiome in the plant could be considered as mostly removed, eliminating then any interaction with the inoculated organisms or cross-effects which could bias the results. The eventual influence of other organisms, such as endophytic bacteria, was not considered in the present study with the hypothesis that the interaction degree between those two unrelated groups might be low. In fact, chloramphenicol was used in culture media to limit the bacteria development, but their 
occurrence into plants might be of course very plausible. Nevertheless, further studies should include this aspect to establish the real influence of these other microorganisms groups in the response given by fungal endophytes.

It is also important to note that the experiment was first performed in the greenhouse in order to assess the endophytes behaviour under the most standard and controlled conditions as possible, reducing the number of variables that could affect their performance. Nevertheless, once the influence of the endophyte inoculation on the studied parameters can be demonstrated under those conditions, it might be also important to evaluate it under field conditions in order to contrast their consistency, as it is known that endophytes performance is clearly dependent on the environmental conditions (Ahlholm et al. 2002). In this case, during the study years, in the field, the relatively high temperatures and low rainfall during April and May might introduce stress factors for plants. This should be taken into account in the interpretation of the results as it is known that fungal endophytes often improve the performance to the plants when those are subjected to biotic or abiotic stresses (Assuero et al. 2006).

According to the evaluation of the disease incidence showed by the endophytes studied, none of the isolates produced any external signs of disease, at least during the experiment duration. Therefore, their potential to act as pathogens could be discarded, validating the premise of their role as endophytes. This aspect was supported by the fact that all of them have been previously described as endophytes before (MaciáVicente et al. 2009; Oliveira Silva et al. 2009; Leyte-Lugo et al. 2013; Perveen et al. 2017; Zheng et al. 2017). This is an important issue in order to use the studied endophytes in eventual future applications as plant growth promoters or as biological agents to improve the performance of forage crops or the nutritional quality of their herbage. Nevertheless, further studies including the evaluation of the production by the endophytes of eventual toxic compounds for livestock should be performed before a commercial use of endophyte-based products.

Regarding herbage yield, although inoculations did not have effect on the herbage biomass in $P$. pratensis when compared to the control, the inoculation with the endophyte E636 (identified as Sporormiella intermedia) produced a decrease in the herbage yield in T. Subterraneum in relation to controls under greenhouse conditions. Similar results were found by Newcombe et al. (2016) with different Sporormiella species reducing the herbage yield of Bromus tectorum $\mathrm{L}$. The inoculation with endophyte $\mathrm{E} 408$ (Byssochlamys spectabilis) also caused a significant decrement in the biomass yield (in both HDM and RDM) in comparison with controls of about a 11\% and a 14\%, respectively. This result was completely opposite to that obtained in the study conducted by Santamaria et al. (2018) where, the inoculation with the same strain of this endophyte, caused an increment of 42\% in the herbage yield of Ornithopus compressus with respect to the control under the exact same infield conditions. This fact might evidence that the effect of endophytes on plant growth might not be only dependent on the fungal species inoculated, as it has been previously stated (Ismail et al., 2018) but also on the plant host where it is inoculated and the interaction that it establishes with the fungus. This inconsistency in the observed effect could be due to a different nature of the interaction fungus*plant host, playing a role as endophyte in some cases or as pathogen in others. Although the pathogenic role might be quite secondary in this case as no disease symptoms were observed during the experiment, it could have been the responsible of such a decrease in the biomass yield. This different behaviour of fungi, playing a role of endophyte or pathogen depending on plant host, has been already stated in several cases (Brader et al. 2017). Further studies should be developed to understand the mechanisms involved in this different behaviour.

Conversely, the inoculation with Fusarium equiseti (E346) produced an increase of about $13 \%$ in the herbage yield of T. subterraneum under greenhouse conditions, and a positive trend (although no significant) in this sense in the field experiment. This fungus has already been considered as a plant growth promoter by Hyakumachi and Kubota (2003). In such a case, its mechanism of action may be related to its capacity to induce resistance to host plants against diseases (Horinouchi et al. 2008). By improving the general health status of the plant, the endophyte could confer a better performance, being able thus to increase biomass yield. Since in our experiments no symptoms of disease were observed in any of the plants, other mechanisms might have been acting to explain this increase in the plant growth. Further experiments should be performed to elucidate such mechanisms. The endophyte Epicoccum nigrum (E179) had a positive effect on the root biomass of $T$. subterraneum. Although this higher root development did not produce a higher herbage yield, it could be the responsible of the healthier aspects of the plants inoculated with this endophyte in the disease severity experiment.

Therefore, it seems clear that the expression of the positive effect of the endophyte might be influenced by its host preference. The metaanalysis made by Mayerhofer et al. (2013) showed that the effect of an endophyte inoculation on root biomass tends to be positive when the fungus had been isolated from the same host species and negative or neutral otherwise. This analysis may be corroborated in our study by several cases. For example, Mucor hiemalis (E063), which had a negative effect on the root biomass, much more pronounced in $T$ subterraneum, had originally been isolated from Poa annua, a very much taxonomically related species to the Poa pratensis used in the experiments.

Regarding the quality parameters of the forage, in the greenhouse, none of the endophytes affected significantly the protein level. The neutral and acidic detergent fibre (NDF and ADF) contents decreased in plants of T. subterraneum inoculated with Byssochlamys spectabilis (E408) and Sporormiella intermedia (E636), respectively. The NDF and ADF contain mostly cellulose and lignin, which are mostly indigestible by nonruminants (Newman and Newman 1992). Consequently, a decrease in the fibre content caused by the endophyte could be considered as 
positive, since an animal nutritive value point of view, as it may imply an increase of the forage digestibility. Soto-Barajas et al. (2015) found significant variations on NDF and lignin content for Lolium perenne when Epichloë endophytes were inoculated, but not on ADF. However, Rodrigo et al. (2017) did not find differences in the fibre content of Lolium rigidum forage when plants were inoculated with the endophyte E408. Once again, the influence of the host preference, and the specific interaction endophyte-plant host, might determine the observed response.

Rasmussen et al. (2012) stated that the infection of Lolium perenne with a Neotyphodium lolii entailed an "up-regulation of fungal cell wall hydrolases", which could explain the reduction of the fibre content. Also, some endophytes can synthetize 1-aminocyclopropane-1-carboxylate (ACC) deaminase (Zabalgogeazcoa et al. 2006; Chaturvedi and Singh 2016; Ali et al. 2019) the immediate precursor of ethylene in plants. These molecules could delay plant maturity, prolonging its vegetative growth stage (Santamaria et al. 2018). Thus, endophytes could act as a plant-growth cycle regulator. Considering that fibre content increase with the growth stage of the plant (Santamaria et al. 2014), such a delay caused by the endophyte may produce a lower fibre content, improving thus forage digestibility.

The interpretation of this effect becomes more complicated when the results of the in-field experiment are also considered, because in such a case the inoculation with E636 caused the opposite effect regarding ADF, increasing also ADL in relation to controls. This could be explained if the production of the phytohormone-like substances by endophytes with effects on the life cycle of the plant indicated above, might be modulated by the environmental conditions. Thus, considering that plants and their endophytes prioritize their survival over growth (Nanda et al. 2019), under the favourable environmental conditions of the greenhouse, the endophyte might respond by producing substances which may enlarge the cycle length. However in the field, the endophyte might detect somehow the high temperatures registered during the 2012/2013 campaign, and might respond by producing phytohormone-like substances which might shorten the vegetative stage of the plant, increasing thus the cellulose and lignin content and decreasing the protein content in the forage, such as it has been indicated previously (Santamaria et al., 2014). The same fact might explain the lower protein content of the plants of $T$. subterraneum inoculated with endophytes E346 and E408, during 2013/2014.

These facts may impact negatively the suitability of an eventual application of these fungi in this forage crop, especially when the aim is oriented to the cattle feeding, as the crude protein is one of the main nutritive quality parameters of forage. However once again, the effect depended on the combination 'endophyte*host*environment', as the inoculation with the endophyte E408 (Byssochlamys spectabilis) caused the opposite effect on P. pratensis, increasing the crude protein of the forage under in-field conditions. This lack of consistency on the effect of endophytes in the crude protein content of the forage has been evidenced in many studies where the results were different in each case, such as those of Santamaría et al. (2018) or Rasmussen et al. (2007).

Regarding the nutrient uptake, the inoculation with Epicoccum nigrum (E179) caused a lower accumulation of Cr, as well as S in the forage of $P$. pratensis and $\mathrm{Ti}$ in the forage of $\mathrm{T}$. subterraneum in the greenhouse experiment. This effect can be considered negative as $\mathrm{Cr}$ and $\mathrm{S}$ are essential nutrients for plants and animals. The role of $\mathrm{Ti}$ is perhaps less clear, since it may improve plant growth, but higher concentrations might negatively affect the uptake of Fe (Cigler et al. 2010; Lyu et al. 2017), although such a situation did not happen here. However, the inoculation with this endophyte did not alter the mineral content of $T$. subterraneum in the field experiment, probably because the effect on the plant uptake may be related to the concentrations in the soil. Thus, in the cases where the mineral concentration in the soil/substrate is not a limiting factor, the effect may go unnoticed.

The effect of the inoculation with the endophyte Sporormiella intermedia (E636) in the greenhouse trial was heterogeneous, as it increased the content of essential nutrients such as the overall uptake of $\mathrm{Ca}$ and $\mathrm{Mn}$ and $\mathrm{Zn}$ in $\mathrm{T}$. subterraneum, but also reduced the overall $\mathrm{Cr}$, Mo and $\mathrm{Na}$, and the Ti content in P. pratensis. However, the main problem found with the inoculation with this endophyte was the increase of the Pb uptake, especially important in the case of the subterranean clover, as it could inhibit the uptake and translocation of other mineral ions (Lamhamdi et al. 2013). Nevertheless, although this situation might imply the unsuitability of this fungus for its use in a livestock feeding system, it could be successfully used for other applications such as phytoremediation of lead in polluted soils due to the mining activity for instance. In any case, further studies should be made to assess the viability of this option since this effect was not observed in the field experiment.

During 2013/2014, the effect on the accumulation of mineral content in the forage was in general more positive than in the previous year. Thus, M. hiemalis (E063) increased the overall uptake of B, Na and $\mathrm{Cr}$ in the case of $T$. subterraneum. Tewari et al. (2005) have already described the capacity of this endophyte for the extraction of $\mathrm{Cr}(\mathrm{VI})$ from substrate by biosorption. Thus, this endophyte may increase the concentration of an essential nutrient for both plants and animals in the forage by binding it to the Trifolium subterraneum biomass. Finally, the inoculation with the endophyte E408 increased significantly the general concentration of $\mathrm{B}, \mathrm{Cu}, \mathrm{Na}, \mathrm{S}$ and $\mathrm{Zn}$ in the forage of both host species, as well as the accumulation of $\mathrm{Cr}, \mathrm{K}, \mathrm{Mg}$ and $\mathrm{Sr}$ in the forage of Poa pratensis. Although all of these minerals are essential nutrients for plants and animals, the increase of the Zinc is of special relevance since Zn deficiency affects more than $20 \%$ of the world's population, being Zn deficiency one of the most important factors causing disease or death in the world (Sauer et al. 2016). Such a deficiency is mainly 
due to the poor Zinc concentration in many soils of the world, including those of the present study, which limits adequate Zn levels in the food, main route of Zn supply in humans and animals (Hotz and Brown 2004). Thus, both endophytes, E346 and E408, which caused an increase of the Zinc uptake and later accumulation in the forage, could be further studied to act as $\mathrm{Zn}$ accumulators in plants once inoculated, to be used in biofortification programs of crops growing in $\mathrm{Zn}$ deficient soils.

In conclusion, the results of this study showed the capacity of endophytes to affect the yield and quality parameters of pasture species. Thus, Fusarium equiseti (E346) increased the herbage yield and Byssochlamys spectabilis (E408) improved forage quality of T. subterraneum. On the other hand, Sporormiella intermedia (E636) caused the increase in the uptake of minerals such as $\mathrm{Ca}, \mathrm{Cu}, \mathrm{Mn}, \mathrm{Pb}, \mathrm{Tl}$ and $\mathrm{Zn}$ together with the total ashes content. Nevertheless, the great influence of the interaction between a fungal strain and its host species has been then clearly evidenced as the results obtained were completely different for either $T$. subterraneum or $P$. pratensis. However, further research is still needed to clarify the mechanisms that affect this interaction in order to optimize its agricultural application.

\section{Declarations}

Funding: This research was funded by Project AGL2011- 27454, granted by the Ministry of Economy and Competitiveness of Spain (the former Ministry of Science and Innovation) and by the European Regional Development Fund (ERDF).

Conflicts of interest: The authors declare no conflict of interest.

Availability of data and material: Associated data to this manuscript has not been deposited

Code availability: Not applicable

Authors' contributions: Rodrigo and Santamaria contributed to the study conception and design. Material preparation, data collection and/or data analysis were performed by the three authors. The first draft of the manuscript was written by García-Latorre and all authors commented on previous versions of the manuscript. All authors read and approved the final manuscript.

\section{References}

1. Ahlholm JU, Helander M, Lehtimäki S, Wäli P, Saikkonen K (2002) Vertically transmitted fungal endophytes: Different responses of hostparasite systems to environmental conditions. Oikos 99:173-183

2. Ali S, Khan SA, Hamayun M, Iqbal A, Khan AL, Hussain A, Shah M (2019) Endophytic fungi from Caralluma acutangula can secrete plant growth promoting enzymes. Fresenius Environ Bull 28:2688-2696

3. AOCS (2006) Official methods of analysis. Association of Official Analytical Chemists, Washington DC

4. Assuero SG, Tognetti JA, Colabelli MR, Agnusdei MG, Petroni EC, Posse MA (2006) Endophyte infection accelerates morpho-physiological responses to water deficit in tall fescue. New Zeal J Agric Res 49:359-370

5. Bastías DA, Gianoli E, Gundel PE (2021) Fungal endophytes can eliminate the plant growth-defence trade-off. New Phytol 230:21052113

6. Bender J, Muntifering RB, Lin JC, Weigel HJ (2006) Growth and nutritive quality of Poa pratensis as influenced by ozone and competition. Environ Pollut 142:109-115

7. Bilal L, Asaf S, Hamayun M, Gul H, Iqbal A, Ullah I, Lee IJ, Hussain A (2018) Plant growth promoting endophytic fungi Aspergillus fumigatus TS1 and Fusarium proliferatum BRL1 produce gibberellins and regulates plant endogenous hormones. Symbiosis 76:117127

8. Bolger TP, Turner NC, Leach BJ (1993) Water use and productivity of annual legume-based pasture systems in the south-west of Western Australia. In: Baker MJ (ed) Proceedings of the XVII International Grassland Congress. New Zealand Grassland Association, Palmerston North, pp 274-275

9. Brader G, Compant S, Vescio K, Mitter B, Trognitz F, Ma L-J, Sessitsch A (2017) Ecology and genomic insights into plant-pathogenic and plant-nonpathogenic endophytes. Annu Rev Phytopathol 55:61-83

10. Bremner JM (1996) Nitrogen total. In: Sparks DL (ed) Methods of soil analysis, Part 3: chemical methods. Soil Science Society of America, Madison, pp 1085-1121

11. Chaturvedi H, Singh V (2016) Potential of bacterial endophytes as plant growth promoting factors. J Plant Pathol Microbiol 7:1-6

12. Cigler P, Olejnickova J, Hruby M, Csefalvay L, Peterka J, Kuzel S (2010) Interactions between iron and titanium metabolism in spinach: A chlorophyll fluorescence study in hydropony. J Plant Physiol 167:1592-1597 
13. Crespo M, Cordero S (1998) Productividad y persistencia de ecotipos autóctonos de trébol subterráneo de la dehesa salmantina en condiciones de pastoreo. Pastos 28:89-95

14. Croce P, De Luca A, Mocioni M, Volterrani M, Beard JB (2001) Warm-season turfgrass species and cultivar characterizations for a Mediterranean climate. Int Turfgrass Soc Res J 9:855-859

15. Dürr G, Kunelius HT, Drapeau R, McRae KB, Fillmore SAE (2005) Herbage yield and composition of Kentucky bluegrass (Poa pratensis L.) cultivars under two harvest systems. Can J Plant Sci 85:631-639

16. Frame J, Charlton JFL, Laidlaw AS (1998) Temperate Forage Legumes. CAB International, New York

17. García-Latorre C, Rodrigo S, Santamaría O (2021) Endophytes as plant nutrient uptake-promoter in plants. In: Maheshwari DK, Dheeman S (eds) Endophytes: mineral nutrient management, vol 3. Sustainable Development and Biodiversity 26, Springer, Cham, pp $247-265$

18. Hazelton P, Murphy B (2016) Interpreting Soil Test Results. What Do All the Numbers Mean? Third. Edition CSIRO Publishing, Clayton South

19. Hodge A (2004) The plastic plant: Root responses to heterogeneous supplies of nutrients. New Phytol 162:9-24

20. Horinouchi H, Katsuyama N, Taguchi Y, Hyakumachi M (2008) Control of Fusarium crown and root rot of tomato in a soil system by combination of a plant growth-promoting fungus, Fusarium equiseti, and biodegradable pots. Crop Prot 27:859-864

21. Hotz C, Brown K (2004) Assessment of the risk of zinc deficiency in populations and options for its control. Food Nutr Bull 25:91-204

22. Hyakumachi M, Kubota M (2003) Fungi as plant growth promoter and disease suppressor. In: Dilip KA (ed) Fungal biotechnology in agricultural food and environmental applications. Basel, New York, pp 101-110

23. Ismail M, Hamayun M, Hussain A, Iqbal A, Khan SA, Lee IJ (2018) Endophytic fungus Aspergillus japonicus mediates host plant growth under normal and heat stress conditions. Biomed Res Int Article ID 7696831

24. Ismail MA, Amin MA, Eid AM, Hassan SE-D, Mahgoub HAM, Lashin I, Abdelwahab AT, Azab E, Gobouri AA, Elkelish A, Fouda A (2021) Comparative study between exogenously applied plant growth hormones versus metabolites of microbial endophytes as plant growthpromoting for Phaseolus vulgaris L. Cells 10:1059

25. Kõljalg U, Nilsson HR, Schigel D, Tedersoo L, Larsson K-H, May TW, Taylor AFS, Jeppesen TS, Frøslev TG, Lindahl BD, Põldmaa K, Saar I, Suija A, Savchenko A, Yatsiuk I, Adojaan K, Ivanov F, Piirmann T, Pöhönen R, Zirk A, Abarenkov K (2020) The taxon hypothesis paradigm On the unambiguous detection and communication of taxa. Microorganisms 8:1910

26. Lamhamdi M, El Galiou O, Bakrim A, Nóvoa-Muñoz JC, Arias-Estévez M, Aarab A, Lafont R (2013) Effect of lead stress on mineral content and growth of wheat (Triticum aestivum) and spinach (Spinacia oleracea) seedlings. Saudi J Biol Sci 20:29-36

27. Leyte-Lugo M, Figueroa M, González MDC, Glenn AE, González-Andrade M, Mata R (2013) Metabolites from the entophytic fungus Sporormiella minimoides isolated from Hintonia latiflora. Phytochemistry 96:273-278

28. Lledó S, Rodrigo S, Poblaciones MJ, Santamaria O (2015) Biomass yield, mineral content, and nutritive value of Poa pratensis as affected by non-clavicipitaceous fungal endophytes. Mycol Prog 14:67 (online version)

29. Lledó S, Rodrigo S, Poblaciones MJ, Santamaria O (2016a) Biomass yield, nutritive value and accumulation of minerals in Trifolium subterraneum L. as affected by fungal endophytes. Plant Soil 405:197-210

30. Lledó S, Santamaría O, Rodrigo S, Poblaciones MJ (2016b) Endophytic mycobiota associated with Trifolium subterraneum growing under semiarid conditions. Ann Appl Biol 168:243-254

31. López-Sánchez A, Perea R, Dirzo R, Roig S (2016) Livestock vs. wild ungulate management in the conservation of Mediterranean dehesas: Implications for oak regeneration. For Ecol Manag 362:99-106

32. Lyu S, Wei X, Chen J, Wang C, Wang X, Pan D (2017) Titanium as a beneficial element for crop production. Front Plant Sci 8:597

33. Maciá-Vicente JG, Rosso LC, Ciancio A, Jansson HB, Lopez-Llorca LV (2009) Colonisation of barley roots by endophytic Fusarium equiseti and Pochonia chlamydosporia: Effects on plant growth and disease. Ann Appl Biol 155:391-401

34. Mayerhofer MS, Kernaghan G, Harper KA (2013) The effects of fungal root endophytes on plant growth: A meta-analysis. Mycorrhiza 23:119-128

35. Moghaddam MSH, Safaie N, Soltani J, Hagh-Doust N (2021) Desert-adapted fungal endophytes induce salinity and drought stress resistance in model crops. Plant Physiol Biochem 160:225-238

36. Moreno G, Pulido FJ (2009) The Functioning, management and persistence of dehesas. In: Rigueiro-Rodríguez A, McAdam J, MosqueraLosada MR (eds) Agroforestry in Europe. Current status and future prospects. Springer, Netherlands, pp 127-160

37. Nanda S, Mohanty B, Joshi RK (2019) Endophyte-mediated host stress tolerance as a means for crop improvement. In: Sumita J (ed) Endophytes and secondary metabolites. Springer, Cham, pp 677-701

38. Newcombe G, Campbell J, Griffith D, Baynes M, Launchbaugh K, Pendleton R (2016) Revisiting the life cycle of dung fungi, including Sordaria fimicola. PLoS One 11(2)

Page 10/19 
39. Newman CW, Newman RK (1992) Nutritional aspects of barley seed structure and composition. In: Shewry PR (ed) Barley: genetics, biochemistry, molecular biology and biotechnology. CAB International, Wallingford, pp 351-368

40. Olea L, San Miguel-Ayanz A (2006) The Spanish dehesa. A traditional Mediterranean silvopastoral system linking production and nature conservation. In: Lloveras J, González-Rodríguez A, Vázquez-Yáñez O, Piñeiro J, Santamaria O, Olea L, Poblaciones MJ (eds) 21 st General Meeting of the European Grassland Federation. Sociedad Española para el Estudio de los Pastos, Madrid, pp 3-13

41. Perveen I, Raza MA, Iqbal T, Naz I, Sehar S, Ahmed S (2017) Isolation of anticancer and antimicrobial metabolites from Epicoccum nigrum; endophyte of Ferula sumbul. Microb Pathog 110:214-224

42. Pinto-Correia T, Ribeiro N, Sá-Sousa P (2011) Introducing the montado, the cork and holm oak agroforestry system of Southern Portugal. Agrofor Syst 82:99-104

43. Rasmussen S, Liu Q, Parsons AJ, Xu H, Sinclair B, Newman JA (2012) Grass-endophyte interactions: A note on the role of monosaccharide transport in the Neotyphodium Iolii-Lolium perenne symbiosis. New Phytol 196:7-12

44. Rasmussen S, Parsons AJ, Bassett S, Christensen MJ, Hume DE, Johnson LJ, Johnson RD, Simpson WR, Stacke C, Voisey CR, Xue H, Newman JA (2007) High nitrogen supply and carbohydrate content reduce fungal endophyte and alkaloid concentration in Lolium perenne. New Phytol 173:787-797

45. Redman RS, Kim YO, Woodward CJDA, Greer C, Espino L, Doty SL, Rodriguez RJ (2011) Increased fitness of rice plants to abiotic stress via habitat adapted symbiosis: A strategy for mitigating impacts of climate change. PLoS One 6(7)

46. Reid G, Dirou J (2004) How to Interpret your Soil Test. Based on Information from Soil Sense leaflet 4/92, Agdex 533. New South Wales Department of Primary industries, New South Wales, Australia

47. Rodrigo S, Santamaria O, Halecker S, Lledó S, Stadler M (2017) Antagonism between Byssochlamys spectabilis (anamorph Paecilomyces variotii) and plant pathogens: Involvement of the bioactive compounds produced by the endophyte. Ann Appl Biol 171:464-476

48. Rodriguez RJ, Henson J, Van Volkenburgh E, Hoy M, Wright L, Beckwith F, Kim YO, Redman RS (2008) Stress tolerance in plants via habitat-adapted symbiosis. ISME J 2:404-416

49. Rodriguez RJ, White JF, Arnold AE, Redman RS (2009) Fungal endophytes: Diversity and functional roles: Tansley review. New Phytol $182: 314-330$

50. San Miguel A (1994) La Dehesa Española. Origen, Topología, Características y Gestión. Escuela Técnica Superior de Montes (Universidad Politécnica), Madrid

51. Santamaria O, Rodrigo S, Poblaciones MJ, Olea L (2014) Fertilizer application (P, K, S, Ca and Mg) on pasture in calcareous dehesas: Effects on herbage yield, botanical composition and nutritive value. Plant Soil Environ 60:303-308

52. Santamaria O, Lledó S, Rodrigo S, Poblaciones MJ (2017) Effect of Fungal Endophytes on Biomass Yield, Nutritive Value and Accumulation of Minerals in Ornithopus compressus. Microb Ecol 74:841-852

53. Santamaria O, Rodrigo S, Lledó S, Poblaciones MJ (2018) Fungal endophytes associated with Ornithopus compressus growing under semiarid conditions. Plant Ecol Divers 11:581-595

54. Sauer AK, Hagmeyer S, Grabrucker AM (2016) Zinc Deficiency. In: Nutritional Deficiency. IntechOpen, London

55. Schardl CL, Craven KD, Speakman S, Stromberg A, Lindstrom A, Yoshida R (2008) A novel test for host-symbiont codivergence indicates ancient origin of fungal endophytes in grasses. Syst Biol 57:483-498

56. Schnabel S, Dahlgren RA, Moreno-Marcos G (2013) Soil and water dynamics. In: Campos P, Huntsinger L, Oviedo Pro JL, Starrs PF, Diaz N, Standiford RB, Montero G (eds) Mediterranean oak woodland working landscapes: Dehesas of Spain and ranchlands of California. Springer-Verlag, New York, pp 91-121

57. Silva MRO, Sena KX, Gusmão NB (2009) Secondary metabolites produced by endophytic fungus Paecilomyces variotii Bainier with antimicrobial activity against Enterococcus faecalis. In: Mendez-Vilas A (ed) Current Research Topics in Applied Microbiology and Microbial Biotechnology - II International Conference on Environmental, Industrial and Applied Microbiology. World Scientific, Seville, Spain, pp 519-520

58. Simón N, Montes F, Díaz-Pinés E, Benavides R, Roig S, Rubio A (2013) Spatial distribution of the soil organic carbon pool in a Holm oak dehesa in Spain. Plant Soil 366:537-549

59. Sosulski FW, Imafidon GI (1990) Amino Acid Composition and Nitrogen-to-Protein Conversion Factors for Animal and Plant Foods. J Agric Food Chem 38:1351-1356

60. Soto-Barajas MC, Zabalgogeazcoa I, Gómez-Fuertes J, González-Blanco V, Vázquez-de-Aldana BR (2016) Epichloë endophytes affect the nutrient and fiber content of Lolium perenne regardless of plant genotype. Plant Soil 405:265-277

61. Tewari N, Vasudevan P, Guha BK (2005) Study on biosorption of Cr(VI) by Mucor hiemalis. Biochem Eng J 23:185-192 
62. Waqas M, Khan AL, Hamayun M, Shahzad R, Kim YH, Choi KS, Lee IJ (2015) Endophytic infection alleviates biotic stress in sunflower through regulation of defence hormones, antioxidants and functional amino acids. Eur J Plant Pathol 141:803-824

63. Ważny R, Rozpądek P, Domka A, Jędrzejczyk RJ, Nosek M, Hubalewska-Mazgaj M, Lichtscheidl I, Kidd P, Turnau K (2021) The effect of endophytic fungi on growth and nickel accumulation in Noccaea hyperaccumulators. Sci Total Environ 768:144666

64. Zabalgogeazcoa Í, Ciudad AG, Vázquez de Aldana BR, Criado BG (2006) Effects of the infection by the fungal endophyte Epichloë festucae in the growth and nutrient content of Festuca rubra. Eur J Agron 24:374-384

65. Zheng YK, Miao CP, Chen HH, Huang FF, Xia YM, Chen YW, Zhao LX (2017) Endophytic fungi harbored in Panax notoginseng: Diversity and potential as biological control agents against host plant pathogens of root-rot disease. J Ginseng Res 41:353-360

66. Zhou XR, Dai L, Xu GF, Shen H (2021) A strain of Phoma species improves drought tolerance of Pinus tabulaeformis. Sci Rep 11:7637

\section{Tables}

Table 1 Origin and identification of the endophytes used in the experiments. For each endophyte, the plant host from which the fungal strain was originally isolated and the Genbank identification data are shown.

\begin{tabular}{|c|c|c|c|c|c|}
\hline $\begin{array}{l}\text { Endophyte } \\
\text { code }\end{array}$ & Plant Host & Identification ${ }^{1}$ & $\begin{array}{l}\text { Genbank } \\
\text { accession No }\end{array}$ & $\begin{array}{l}\text { GenBank } \\
\text { Identity (\%) }\end{array}$ & $\begin{array}{l}\text { UNITE } \\
\text { Identity (\%) }\end{array}$ \\
\hline E063 & $\begin{array}{l}\text { Ornithopus } \\
\text { compressus L. }\end{array}$ & Mucor hiemalis Wehmer & KP899388 & 99,85 & 99 \\
\hline E179 & $\begin{array}{l}\text { Medicago } \\
\text { polymorpha L. }\end{array}$ & Epicoccum nigrum Link & KP698340 & 99,63 & 99 \\
\hline E346 & $\begin{array}{l}\text { Medicago } \\
\text { polymorpha L. }\end{array}$ & Fusarium equiseti (Corda) Sacc. & KP899431 & 99,82 & 99 \\
\hline E408 & $\begin{array}{l}\text { Biserrula } \\
\text { pelecinus L. }\end{array}$ & $\begin{array}{l}\text { Byssochlamys spectabilis (Udagawa \& Shoji } \\
\text { Suzuki) Houbraken \& Samson }\end{array}$ & KP899436 & 100 & 100 \\
\hline E636 & $\begin{array}{l}\text { Ornithopus } \\
\text { compressus L. }\end{array}$ & $\begin{array}{l}\text { Sporormiella intermedia (Auersw.) S.I. Ahmed \&Cain } \\
\text { ex Kobayasi }\end{array}$ & KP698330 & 99,80 & 99 \\
\hline
\end{tabular}

${ }^{1}$ Based on morphological characteristics and by comparing to ITS sequences in GenBank and UNITE (version 8.3 ) with a similarity $\geq 99 \%$

Table 2 Soil substrate (greenhouse experiment) and soil (field experiment) properties expressed as mean \pm standard error (SE) from four samples $(n=4)$. 


\begin{tabular}{|c|c|c|c|}
\hline Parameter & Greenhouse substrate & Field soil & Normal range for plant growth. \\
\hline $\mathrm{pH}$ & $4.43 \pm 0.01$ & $5.35 \pm 0.12$ & $4.3-6.5$ \\
\hline $\mathrm{EC}\left(\mathrm{S} \mathrm{m}^{-1}\right)$ & $0.51 \pm 0.01$ & $0.86 \pm 0.06$ & $>0.2$ \\
\hline $\mathrm{N}_{\text {tot }}\left(\mathrm{g} \mathrm{kg}^{-1}\right)$ & $9.60 \pm 0.20$ & $1.28 \pm 0.13$ & $0-10$ \\
\hline$P_{\text {Olsen }}\left(\mathrm{mg} \mathrm{kg}^{-1}\right)$ & $5.11 \pm 0.30$ & $10.03 \pm 1.65$ & $10-17$ \\
\hline $\mathrm{K}\left(\mathrm{mg} \mathrm{kg}^{-1}\right)$ & $238.51 \pm 0.01$ & $115.3 \pm 27.90$ & $>200$ \\
\hline $\mathrm{Al}_{\text {tot }}\left(\mathrm{g} \mathrm{kg}^{-1}\right)$ & $0.53 \pm 0.0$ & $17.94 \pm 0.89$ & $0-15$ \\
\hline $\mathrm{B}_{\text {tot }}\left(\mathrm{mg} \mathrm{kg}^{-1}\right)$ & $3.19 \pm 0.17$ & $5.52 \pm 0.12$ & $0.5-4$ \\
\hline $\mathrm{Ca}_{\text {tot }}\left(\mathrm{g} \mathrm{kg}^{-1}\right)$ & $5.16 \pm 0.50$ & $0.83 \pm 0.04$ & $>1$ \\
\hline $\mathrm{Cr}_{\text {tot }}\left(\mathrm{mg} \mathrm{kg}^{-1}\right)$ & $1.63 \pm 0.21$ & $25.77 \pm 0.66$ & $5-1000$ \\
\hline $\mathrm{Cu}_{\text {tot }}\left(\mathrm{mg} \mathrm{kg}^{-1}\right)$ & $5.19 \pm 0.50$ & $6.84 \pm 0.31$ & $2-50$ \\
\hline$F e_{\text {tot }}\left(\mathrm{g} \mathrm{kg}^{-1}\right)$ & $0.44 \pm 0.85$ & $11.40 \pm 0.49$ & - \\
\hline $\mathrm{Mg}_{\text {tot }}\left(\mathrm{g} \mathrm{kg}^{-1}\right)$ & $0.52 \pm 0.04$ & $1.03 \pm 0.05$ & $>0.12$ \\
\hline $\mathrm{Mn}_{\text {tot }}\left(\mathrm{mg} \mathrm{kg}^{-1}\right)$ & $26.55 \pm 2.51$ & $539.50 \pm 39.46$ & - \\
\hline $\mathrm{Mo}_{\text {tot }}\left(\mathrm{mg} \mathrm{kg}^{-1}\right)$ & $<0.01$ & $<0.01$ & $<2$ \\
\hline $\mathrm{Na}_{\text {tot }}\left(\mathrm{g} \mathrm{kg}^{-1}\right)$ & $3.86 \pm 067$ & $0.28 \pm 0.01$ & $1.4-2.8$ \\
\hline $\mathrm{Ni}_{\text {tot }}\left(\mathrm{mg} \mathrm{kg}^{-1}\right)$ & $1.03 \pm 0.13$ & $12.73 \pm 0.43$ & $<60$ \\
\hline $\mathrm{Pb}_{\text {tot }}\left(\mathrm{mg} \mathrm{kg}^{-1}\right)$ & $2.07 \pm 0.18$ & $16.09 \pm 0.85$ & $<150$ \\
\hline $\mathrm{S}_{\text {tot }}\left(\mathrm{mg} \mathrm{kg}^{-1}\right)$ & $765.59 \pm 13.46$ & $77.73 \pm 5.57$ & $10-20$ \\
\hline $\mathrm{Se}_{\text {tot }}\left(\mathrm{mg} \mathrm{kg}^{-1}\right)$ & $<0.01$ & $0.82 \pm 0.14$ & $<5$ \\
\hline $\mathrm{Sr}_{\text {tot }}\left(\mathrm{mg} \mathrm{kg}^{-1}\right)$ & $18.21 \pm 1.81$ & $13.30 \pm 0.36$ & - \\
\hline $\mathrm{Ti}_{\text {tot }}\left(\mathrm{mg} \mathrm{kg}^{-1}\right)$ & $22.04 \pm 1.46$ & $165.76 \pm 5.14$ & - \\
\hline $\mathrm{Zn}_{\mathrm{tot}}\left(\mathrm{mg} \mathrm{kg}^{-1}\right)$ & $6.86 \pm 56.51$ & $18.99 \pm 0.66$ & $<200$ \\
\hline
\end{tabular}

Table 3 Summary of the analysis of variances (ANOVAs) showing the effect of endophyte, host and their interaction on each parameter evaluated in both experiments (under greenhouse and field conditions) and in both study years. DF, degree of freedom; $F$ values, including the level of significance ( $\left.{ }^{*} P \leq 0.05, * \star P \leq 0.01, * \star * P \leq 0.001\right)$ are shown in the rest of the rows. 


\begin{tabular}{|c|c|c|c|c|c|c|}
\hline \multirow[t]{2}{*}{ Source } & \multicolumn{3}{|l|}{$2012 / 2013$} & \multicolumn{3}{|l|}{$2013 / 2014$} \\
\hline & Endophyte & Host & Endophyte x Host & Endophyte & Host & Endophyte x Host \\
\hline DF & 2 & 1 & 2 & 3 & 1 & 3 \\
\hline \multicolumn{7}{|c|}{ Greenhouse experiment } \\
\hline AUDCP & $5.13^{\star}$ & 8018 ** & 2.22 & 1.19 & $110.41^{\star \star \star}$ & 1.29 \\
\hline $\mathrm{HDM}\left(\mathrm{g} \mathrm{pot}^{-1}\right)$ & $6.23^{*}$ & $213.65^{\star \star \star}$ & $5.19 *$ & 3.18 & $227.28^{\star \star \star}$ & $4.17^{\star}$ \\
\hline $\operatorname{RDM}\left(\mathrm{g} \mathrm{pot}^{-1}\right)$ & 0.09 & $157.67^{\star \star \star}$ & $6.86^{\star}$ & $4.30 *$ & 0.51 & 2.70 \\
\hline $\mathrm{CP}(\%)$ & 2.01 & $491.82^{\star \star}$ & 3.86 & 1.08 & $26.53^{\star}$ & 0.97 \\
\hline NDF (\%) & 3.67 & $286.62^{*}$ & 2.59 & 0.30 & $150.39 \star \star$ & 1.88 \\
\hline ADF (\%) & $9.23^{*}$ & 14.98 & 1.04 & 1.73 & 1.11 & 2.33 \\
\hline ADL $(\%)$ & 3.42 & $30.93^{*}$ & 2.12 & 2.45 & 0.82 & 1.59 \\
\hline Ashes (\%) & 3.8 & 4.23 & $9.96 *$ & 0.43 & $32.94^{\star}$ & 0.94 \\
\hline \multicolumn{7}{|c|}{ Field experiment } \\
\hline FDM $\left(\mathrm{g} \mathrm{pot}^{-1}\right)$ & 1.9 & - & - & 0.31 & $1227.18 * \star \star$ & 0.78 \\
\hline CP (\%) & 3.65 & - & - & 2.89 & $26.38^{\star \star}$ & $5.2^{\star}$ \\
\hline NDF (\%) & 1.66 & - & - & 2.26 & 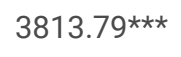 & $1.42^{\star}$ \\
\hline ADF (\%) & $6.26 *$ & - & - & 1.32 & $18.01 * \star$ & 1.40 \\
\hline ADL (\%) & $37.77 * \star \star$ & - & - & 0.08 & $25.52^{\star \star}$ & 0.44 \\
\hline Ashes (\%) & - & - & - & 0.06 & $18.16^{\star \star}$ & 0.57 \\
\hline
\end{tabular}

AUDCP: area under the disease progress curve $(n=5)$; HDM: herbage dry matter in the greenhouse experiment $(n=5)$; RDM: root dry matter ( $n$ $=5)$; CP: crude protein ( $n=3)$; NDF: neutral detergent fibre $(n=3)$; ADF: acid detergent fibre $(n=3)$; ADL: acid detergent lignin ( $n=3)$; Ashes $(n$ = 3). FDM: herbage dry matter in the field experiment $(n=5)$. In 2012/2013, in the field experiment only T. Subterraneum could be included.

Table 4 Effect of the endophyte (endo), host and its interaction on the concentration of each mineral in the herbage obtained from endophyteinoculated plants in the greenhouse experiment in 2012/2013. In the last three rows a summary of ANOVA is shown including the $F$ values with the level of significance $(* p \leq 0.05 ; * \star p \leq 0.01 ; * \star * p \leq 0.001)$ when appropriate. 


\begin{tabular}{|c|c|c|c|c|c|c|c|c|}
\hline & & Nutrient & $\mathrm{Ca}\left(\mathrm{g} 100 \mathrm{~g}^{-1}\right)$ & $\mathrm{Cu}\left(\mathrm{mg} \mathrm{kg}^{-1}\right)$ & $\mathrm{Mn}\left(\mathrm{mg} \mathrm{kg}^{-1}\right)$ & $\mathrm{Pb}\left(\mathrm{mg} \mathrm{kg}^{-1}\right)$ & $\mathrm{TI}\left(\mathrm{mg} \mathrm{kg}^{-1}\right)$ & $\mathrm{Zn}\left(\mathrm{mg} \mathrm{kg}^{-1}\right)$ \\
\hline \multirow[t]{6}{*}{ Interaction } & \multirow[t]{3}{*}{ TS } & E179 & $1.9 \pm 0.1 b$ & $7.8 \pm 0.4 b$ & $146.2 \pm 2.5 \mathrm{c}$ & $0.3 \pm 0.0 \mathrm{c}$ & $12.9 \pm 0.5 b c$ & $43.2 \pm 2.9 \mathrm{bc}$ \\
\hline & & E636 & $2.6 \pm 0.1 \mathrm{a}$ & $11.3 \pm 0.4 \mathrm{a}$ & $241.1 \pm 11.6 b$ & $1.3 \pm 0.1 b$ & $22.4 \pm 0.6 \mathrm{a}$ & $59.1 \pm 2.2 \mathrm{a}$ \\
\hline & & E0 & $2.00 \pm 0.1 b$ & $7.8 \pm 1.0 \mathrm{~b}$ & $160.9 \pm 16.5 c$ & $0.4 \pm 0.1 \mathrm{c}$ & $13.6 \pm 0.6 \mathrm{c}$ & $47.3 \pm 6.5 \mathrm{bc}$ \\
\hline & \multirow[t]{3}{*}{$\mathrm{PP}$} & E179 & $0.7 \pm 0.2 c$ & $6.50 \pm 0.5 b c$ & $318.0 \pm 37.4 \mathrm{a}$ & $1.5 \pm 0.1 \mathrm{ab}$ & $17.9 \pm 3.8 \mathrm{abc}$ & $49.5 \pm 2.8 \mathrm{ab}$ \\
\hline & & E636 & $0.7 \pm 0.0 \mathrm{c}$ & $4.51 \pm 0.4 \mathrm{~d}$ & $320.7 \pm 23.5 a$ & $1.8 \pm 0.2 \mathrm{a}$ & $18.3 \pm 1.8 \mathrm{ab}$ & $38.9 \pm 1.1 \mathrm{c}$ \\
\hline & & EO & $0.8 \pm 0.0 \mathrm{c}$ & $5.23 \pm 0.3 \mathrm{~cd}$ & $352.9 \pm 8.9 \mathrm{a}$ & $1.8 \pm 0.1 \mathrm{a}$ & $18.9 \pm 0.4 \mathrm{a}$ & $45.1 \pm 1.5 \mathrm{bc}$ \\
\hline \multirow{2}{*}{\multicolumn{2}{|c|}{ Host }} & TS & $2.1 \pm 0.1 \mathrm{a}$ & $9.0 \pm 0.7 a$ & $330.5 \pm 15.9$ a & $1.7 \pm 0.2 \mathrm{a}$ & $18.3 \pm 1.5$ & $49.9 \pm 3.2$ \\
\hline & & PP & $0.7 \pm 0.1 \mathrm{~b}$ & $5.4 \pm 0.4 b$ & $182.7 \pm 14.2 \mathrm{~b}$ & $0.7 \pm 0.1 b$ & $16.3 \pm 1.2$ & $44.5 \pm 1.8$ \\
\hline \multirow{3}{*}{\multicolumn{2}{|c|}{ Endo }} & E179 & $1.3 \pm 0.3 b$ & $7.2 \pm 0.4$ & $232.1 \pm 41.9$ & $0.9 \pm 0.3 b$ & $15.3 \pm 2.0 \mathrm{~b}$ & $46.3 \pm 2.3$ \\
\hline & & E636 & $1.6 \pm 0.4 \mathrm{a}$ & $7.9 \pm 1.6$ & $280.9 \pm 21.3$ & $1.6 \pm 0.0 \mathrm{a}$ & $20.3 \pm 1.2 \mathrm{a}$ & $49.0 \pm 4.7$ \\
\hline & & E0 & $1.4 \pm 0.3 b$ & $6.5 \pm 0.8$ & $256.9 \pm 43.7$ & $1.1 \pm 0.3 b$ & $16.3 \pm 1.2 b$ & $46.2 \pm 3.0$ \\
\hline \multirow{3}{*}{\multicolumn{2}{|c|}{ ANOVA }} & Endo $(E)$ & $13.62^{\star \star}$ & 2.63 & 2.31 & $19.6^{\star \star}$ & $6.9 *$ & 0.38 \\
\hline & & Host $(H)$ & $550.57 \star \star$ & $92.39 *$ & $69.64^{\star}$ & $64.7^{\star}$ & 0.8 & 4.20 \\
\hline & & $E^{*} \mathrm{H}$ & $8.45^{\star}$ & $13.65^{\star}$ & $8.36^{\star}$ & $62.6^{\star \star \star}$ & $8.3^{*}$ & $11.01^{*}$ \\
\hline
\end{tabular}

Within each main effect or interaction, averages in the same column with different letters are significantly different according to LSD test. Three repetitions were made for each treatment $(\mathrm{n}=3)$. E179 (Epiccocum nigrum), E636( Sporormiella intermedia), E0 (control).

Table 5 Effect of the endophyte (endo), host and its interaction on the concentration of each mineral in the herbage obtained from endophyteinoculated plants in the field experiment in 2013/2014. In the last three rows a summary of ANOVA is shown including the $F$ values with the level of significance $(* p \leq 0.05 ; * \star p \leq 0.01 ; * \star * p \leq 0.001)$ when appropriate. 


\begin{tabular}{|c|c|c|c|c|c|c|c|c|c|c|c|}
\hline Nutrient & & & $\begin{array}{l}\mathrm{B}(\mathrm{mg} \\
\left.\mathrm{kg}^{-1}\right)\end{array}$ & $\begin{array}{l}\mathrm{Cr}(\mathrm{mg} \\
\left.\mathrm{kg}^{-1}\right)\end{array}$ & $\begin{array}{l}\mathrm{Cu}(\mathrm{mg} \\
\left.\mathrm{kg}^{-1}\right)\end{array}$ & $\begin{array}{l}K(g 100 \\
\left.g^{-1}\right)\end{array}$ & $\begin{array}{l}\mathrm{Mg}(\mathrm{g} \\
\left.100 \mathrm{~g}^{-1}\right)\end{array}$ & $\begin{array}{l}\mathrm{Na}(\mathrm{g} 100 \\
\left.\mathrm{g}^{-1}\right)\end{array}$ & $\begin{array}{l}S\left(g 100 g^{-}\right. \\
1)\end{array}$ & $\begin{array}{l}\mathrm{Sr} \\
(\mathrm{mg} \\
\left.\mathrm{kg}^{-1}\right)\end{array}$ & $\begin{array}{l}\mathrm{Zn}(\mathrm{mg} \\
\left.\mathrm{kg}^{-1}\right)\end{array}$ \\
\hline \multirow[t]{8}{*}{ Interaction } & \multirow[t]{4}{*}{ TS } & E063 & $\begin{array}{l}19.8 \pm \\
1.6 \mathrm{a}\end{array}$ & $\begin{array}{l}0.6 \pm 0.1 \\
c\end{array}$ & $\begin{array}{l}4.5 \pm \\
0.5 \mathrm{~d}\end{array}$ & $\begin{array}{l}0.6 \pm 0.1 \\
c\end{array}$ & $\begin{array}{l}0.5 \pm 0.1 \\
a\end{array}$ & $0.6 \pm 0.1 a$ & $0.5 \pm 0.1 a$ & $\begin{array}{l}55.9 \pm \\
1.1 \mathrm{bc}\end{array}$ & $\begin{array}{l}44.3 \pm \\
4.6 \mathrm{bcd}\end{array}$ \\
\hline & & E346 & $\begin{array}{l}15.0 \pm \\
0.4 \mathrm{~b}\end{array}$ & $\begin{array}{l}0.4 \pm 0.1 \\
d\end{array}$ & $\begin{array}{l}4.0 \pm \\
0.1 \mathrm{~d}\end{array}$ & $\begin{array}{l}0.5 \pm 0.1 \\
c\end{array}$ & $\begin{array}{l}0.5 \pm 0.1 \\
a\end{array}$ & $0.5 \pm 0.1 c$ & $0.4 \pm 0.1 b$ & $\begin{array}{l}56.9 \pm \\
2.2 \\
b c\end{array}$ & $\begin{array}{l}35.1 \pm \\
2.5 \mathrm{e}\end{array}$ \\
\hline & & E408 & $\begin{array}{l}18.7 \pm \\
0.5 a\end{array}$ & $\begin{array}{l}0.4 \pm 0.1 \\
\mathrm{~cd}\end{array}$ & $\begin{array}{l}4.4 \pm \\
0.3 \mathrm{~d}\end{array}$ & $\begin{array}{l}0.5 \pm 0.1 \\
c\end{array}$ & $\begin{array}{l}0.5 \pm 0.1 \\
a\end{array}$ & $0.6 \pm 0.1 b$ & $0.5 \pm 0.1 \mathrm{a}$ & $\begin{array}{l}55.6 \pm \\
0.5 c\end{array}$ & $\begin{array}{l}42.1 \pm 1.8 \\
\text { cde }\end{array}$ \\
\hline & & EO & $\begin{array}{l}15.6 \pm \\
0.5 \mathrm{~b}\end{array}$ & $0.4 \pm 0.1$ & $\begin{array}{l}4.6 \pm \\
0.3 \mathrm{~d}\end{array}$ & $\begin{array}{l}0.5 \pm 0.1 \\
c\end{array}$ & $\begin{array}{l}0.5 \pm 0.1 \\
\mathrm{a}\end{array}$ & $0.5 \pm 0.1 \mathrm{c}$ & $0.4 \pm 0.1 b$ & $\begin{array}{l}62.1 \pm \\
1.2 \mathrm{bc}\end{array}$ & $\begin{array}{l}38.7 \pm \\
1.1 \mathrm{de}\end{array}$ \\
\hline & \multirow[t]{4}{*}{ PP } & E063 & $\begin{array}{l}6.1 \pm \\
0.4 \mathrm{c}\end{array}$ & $\begin{array}{l}1.6 \pm 0.1 \\
b\end{array}$ & $\begin{array}{l}7.3 \pm \\
0.3 \mathrm{bc}\end{array}$ & $\begin{array}{l}1.5 \pm 0.1 \\
b\end{array}$ & $\begin{array}{l}0.3 \pm 0.1 \\
c\end{array}$ & $0.1 \pm 0.1 \mathrm{~d}$ & $0.3 \pm 0.1 \mathrm{c}$ & $\begin{array}{l}62.4 \pm \\
5.3 \mathrm{~b}\end{array}$ & $\begin{array}{l}50.4 \pm \\
3.8 \mathrm{bc}\end{array}$ \\
\hline & & E346 & $\begin{array}{l}6.4 \pm \\
0.3 c\end{array}$ & $\begin{array}{l}1.8 \pm 0.1 \\
b\end{array}$ & $\begin{array}{l}8.1 \pm \\
0.4 \mathrm{ab}\end{array}$ & $\begin{array}{l}1.7 \pm 0.1 \\
a\end{array}$ & $\begin{array}{l}0.3 \pm 0.1 \\
\mathrm{bc}\end{array}$ & $0.1 \pm 0.1 d$ & $0.3 \pm 0.1 c$ & $\begin{array}{l}71.6 \pm \\
1.2 \mathrm{a}\end{array}$ & $\begin{array}{l}52.6 \pm \\
2.4 \mathrm{~b}\end{array}$ \\
\hline & & E408 & $\begin{array}{l}6.7 \pm \\
0.1 \mathrm{c}\end{array}$ & $\begin{array}{l}2.3 \pm 0.1 \\
a\end{array}$ & $\begin{array}{l}8.8 \pm \\
0.1 \mathrm{a}\end{array}$ & $\begin{array}{l}1.7 \pm 0.1 \\
a\end{array}$ & $\begin{array}{l}0.4 \pm 0.1 \\
\mathrm{~b}\end{array}$ & $0.1 \pm 0.1 \mathrm{~d}$ & $0.3 \pm 0.1 \mathrm{c}$ & $\begin{array}{l}71.2 \pm \\
0.6 \mathrm{a}\end{array}$ & $\begin{array}{l}62.2 \pm \\
1.8 \mathrm{a}\end{array}$ \\
\hline & & EO & $\begin{array}{l}7.0 \pm \\
0.2 \mathrm{c}\end{array}$ & $\begin{array}{l}1.8 \pm 0.1 \\
b\end{array}$ & $\begin{array}{l}7.1 \pm \\
0.4 \mathrm{c}\end{array}$ & $\begin{array}{l}1.5 \pm 0.1 \\
b\end{array}$ & $\begin{array}{l}0.3 \pm 0.1 \\
C\end{array}$ & $0.1 \pm 0.1 \mathrm{~d}$ & $0.3 \pm 0.1 \mathrm{c}$ & $\begin{array}{l}59.9 \pm \\
1.7 \mathrm{bc}\end{array}$ & $\begin{array}{l}49.9 \pm \\
2.8 \mathrm{bc}\end{array}$ \\
\hline \multirow{2}{*}{\multicolumn{2}{|c|}{ Host }} & TS & $\begin{array}{l}17.3 \pm \\
0.7 \mathrm{a}\end{array}$ & $\begin{array}{l}0.4 \pm \\
0.0 \mathrm{~b}\end{array}$ & $\begin{array}{l}4.4 \pm \\
0.2 \mathrm{~b}\end{array}$ & $\begin{array}{l}0.5 \pm \\
0.1 \mathrm{~b}\end{array}$ & $\begin{array}{l}0.5 \pm \\
0.1 \mathrm{a}\end{array}$ & $0.6 \pm 0.1 \mathrm{a}$ & $0.5 \pm 0.1 \mathrm{a}$ & $\begin{array}{l}57.6 \pm \\
1.0\end{array}$ & $\begin{array}{l}40.1 \pm \\
1.6 b\end{array}$ \\
\hline & & PP & $\begin{array}{l}6.6 \pm \\
0.1 \mathrm{~b}\end{array}$ & $\begin{array}{l}1.9 \pm \\
0.1 \mathrm{a}\end{array}$ & $\begin{array}{l}7.8 \pm \\
0.2 \mathrm{a}\end{array}$ & $\begin{array}{l}1.6 \pm \\
0.1 \mathrm{a}\end{array}$ & $\begin{array}{l}0.3 \pm \\
0.1 \mathrm{~b}\end{array}$ & $0.1 \pm 0.1 b$ & $0.3 \pm 0.1 b$ & $\begin{array}{l}66.3 \pm \\
2.0\end{array}$ & $\begin{array}{l}53.8 \pm \\
1.9 a\end{array}$ \\
\hline \multirow{4}{*}{\multicolumn{2}{|c|}{ Endo }} & E063 & $\begin{array}{l}13.0 \pm \\
3.1 \mathrm{a}\end{array}$ & $1.1 \pm 0.2$ & $\begin{array}{l}5.9 \pm 0.7 \\
b\end{array}$ & $1.1 \pm 0.2$ & $0.4 \pm 0.1$ & $0.4 \pm 0.1 \mathrm{a}$ & $\begin{array}{l}0.4 \pm 0.1 \\
a b\end{array}$ & $\begin{array}{l}59.1 \pm \\
2.8\end{array}$ & $\begin{array}{l}47.4 \pm 3.0 \\
a b\end{array}$ \\
\hline & & E346 & $\begin{array}{l}10.7 \pm \\
1.9 \mathrm{~b}\end{array}$ & $1.1 \pm 0.3$ & $\begin{array}{l}6.1 \pm 0.9 \\
a b\end{array}$ & $1.1 \pm 0.3$ & $0.4 \pm 0.1$ & $\begin{array}{l}0.3 \pm 0.1 \\
\mathrm{bc}\end{array}$ & $0.3 \pm 0.1 c$ & $\begin{array}{l}64.3 \pm \\
3.5\end{array}$ & $\begin{array}{l}43.9 \pm 4.2 \\
b\end{array}$ \\
\hline & & E408 & $\begin{array}{l}12.7 \pm \\
2.7 \mathrm{a}\end{array}$ & $1.4 \pm 0.4$ & $\begin{array}{l}6.6 \pm 1.0 \\
a\end{array}$ & $1.1 \pm 0.3$ & $0.4 \pm 0.1$ & $\begin{array}{l}0.3 \pm 0.1 \\
a b\end{array}$ & $0.4 \pm 0.1 \mathrm{a}$ & $\begin{array}{l}63.4 \pm \\
3.6\end{array}$ & $\begin{array}{l}52.1 \pm 4.7 \\
a\end{array}$ \\
\hline & & E0 & $\begin{array}{l}11.3 \pm \\
1.9 \mathrm{~b}\end{array}$ & $1.1 \pm 0.3$ & $\begin{array}{l}5.8 \pm 0.6 \\
b\end{array}$ & $1.0 \pm 0.2$ & $0.4 \pm 0.1$ & $0.3 \pm 0.1 \mathrm{c}$ & $\begin{array}{l}0.4 \pm 0.1 \\
\mathrm{bc}\end{array}$ & $\begin{array}{l}61.0 \pm \\
0.8\end{array}$ & $\begin{array}{l}44.3 \pm 2.8 \\
b\end{array}$ \\
\hline \multirow{3}{*}{\multicolumn{2}{|c|}{ ANOVA }} & $\begin{array}{l}\text { Endo } \\
(E)\end{array}$ & $9.75^{\star \star}$ & 3.99 & $4.53^{\star}$ & 1.62 & 9,62 & $7.15^{\star}$ & $6.64 *$ & 2.66 & $6.47 *$ \\
\hline & & $\begin{array}{l}\text { Host } \\
(\mathrm{H})\end{array}$ & $217.7^{\star \star \star}$ & $417.59 * \star$ & 116.59 ** & $900.07 * \star$ & $115.09 \star \star$ & $11953.5^{\star \star \star}$ & 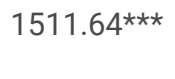 & 13.84 & 27.81 \\
\hline & & $\mathrm{E} * \mathrm{H}$ & $6.2^{\star}$ & $21.25^{\star \star}$ & 3.37 & $6.55^{\star \star}$ & $5.14^{\star}$ & 4.42 & 1.73 & $8.11^{\star}$ & 1.89 \\
\hline
\end{tabular}

Within each main effect or interaction, averages in the same column with different letters are significantly different according to LSD test. Three repetitions were made for each treatment $(\mathrm{n}=3$ ). E0 (control), E063 (Mucor hiemalis), E346 (Fusarium equiseti) and E408 (Byssochlamys spectabilis).

Figures 

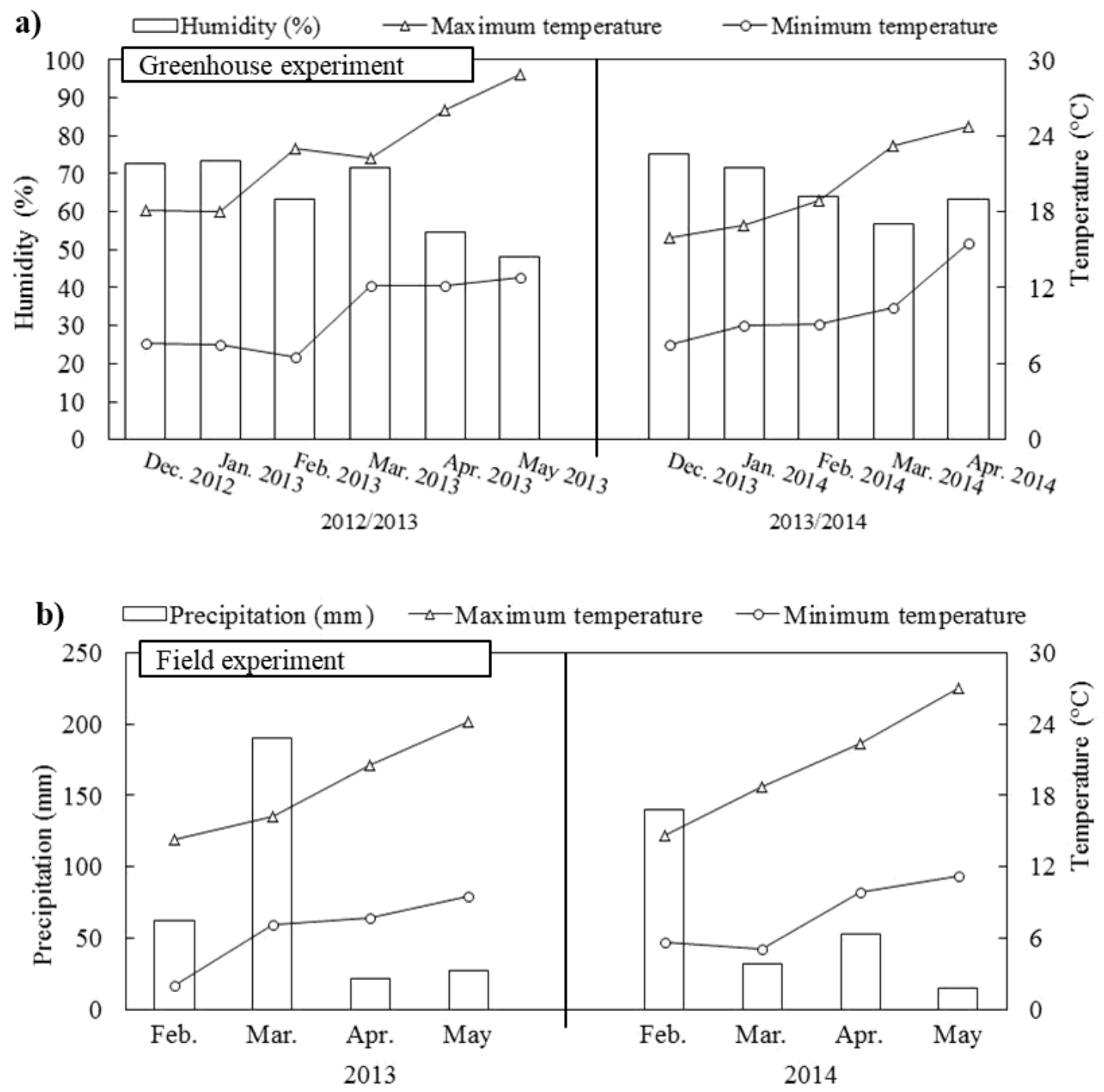

Figure 1

Mean relative humidity or monthly precipitation and mean maximum and minimum temperatures during the greenhouse (a) and field (b) experiments in the two study years (2012/2013 and 2013/2014). 


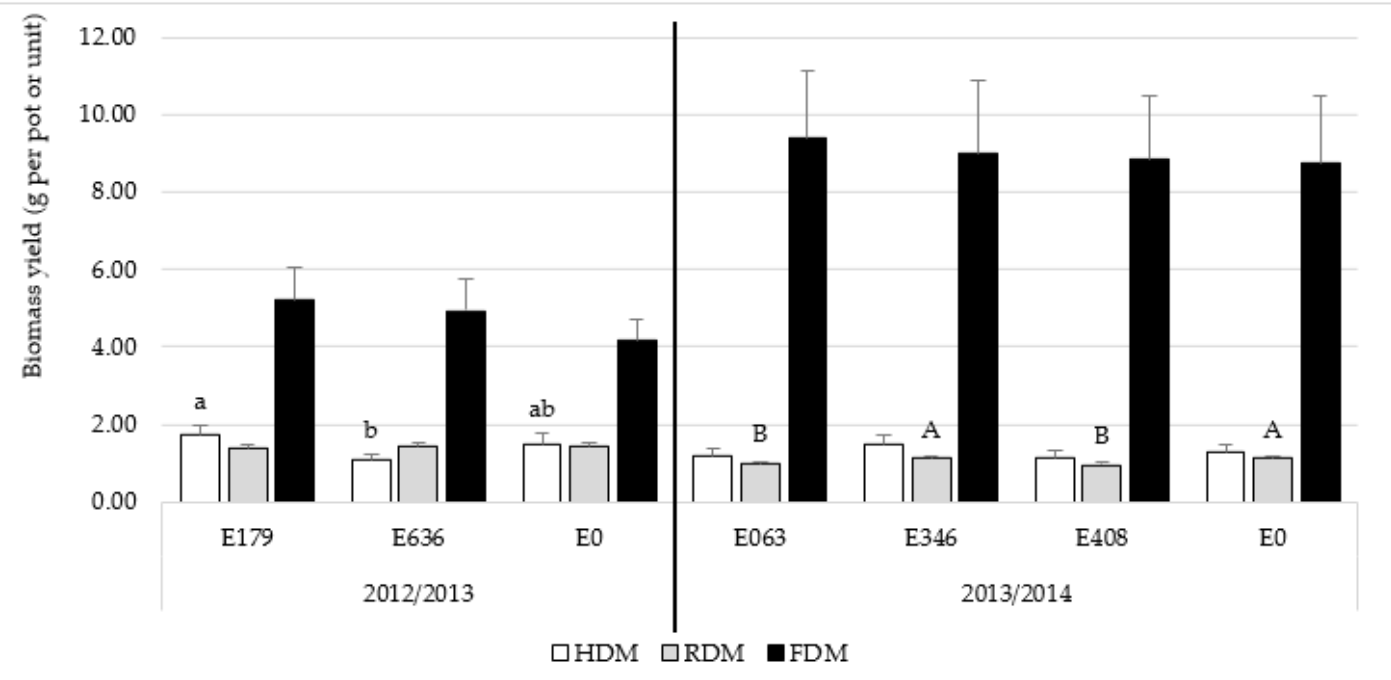

(a)

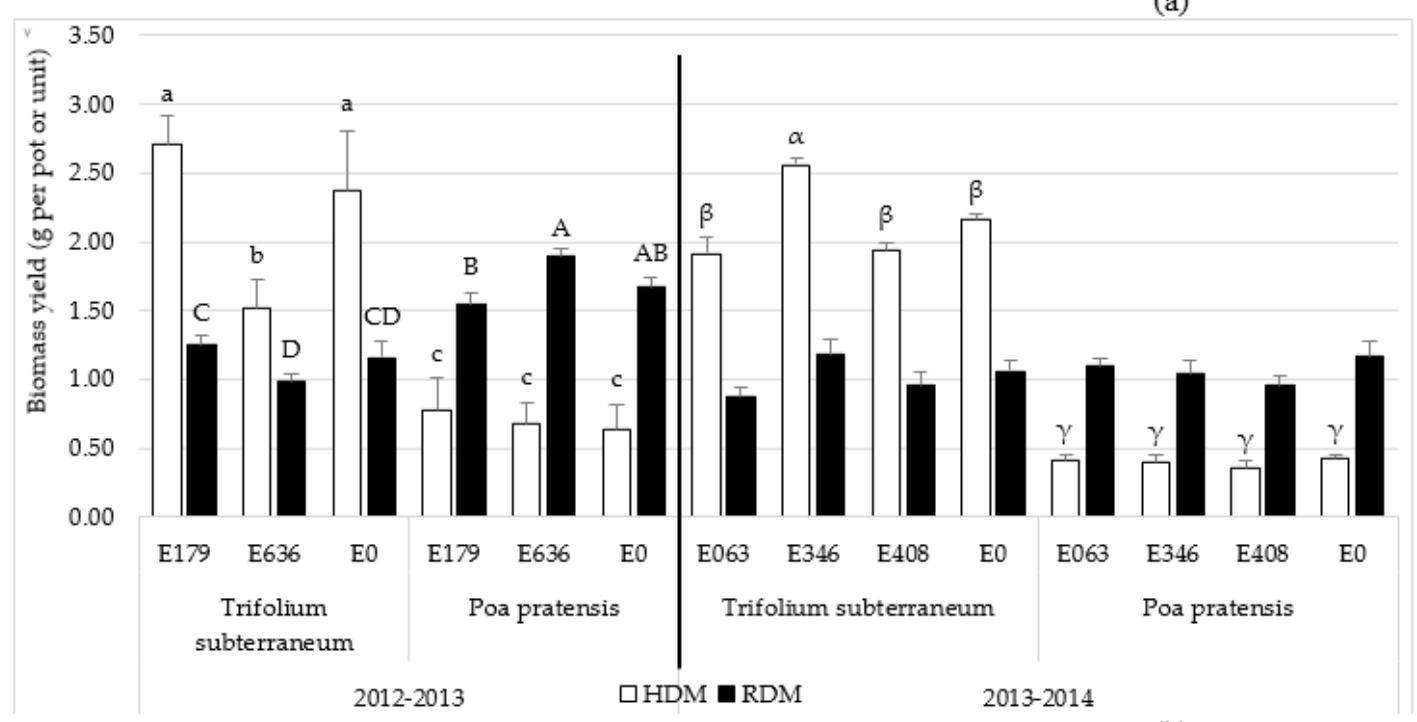

(b)

Figure 2

Effect of a) endophyte inoculation and b) endophyte $x$ host interaction on biomass yield (herbage dry matter in the field: FDM; herbage dry matter in the greenhouse: HDM and root dry matter in the greenhouse: RDM) in both years of study. Untransformed data is shown. Charts indicate means $(n=5)$ and error bars indicate standard error. Within each analysis, parameter and year, different letters mean significant differences between means according to LSD test $(p \leq 0.05)$. In order to make the differences clearer, a different set of letters was assigned to each case (lowercase letters for HDM in 2012/13, Greek letters for HDM in 2013/14 and uppercase letters for RDM in both years. E0 (control), E063 (Mucor hiemalis), E179 (Epicoccum nigrum), E346 (Fusarium equiseti), E408 (Byssochlamys spectabilis and E636 (Sporormiella intermedia). 

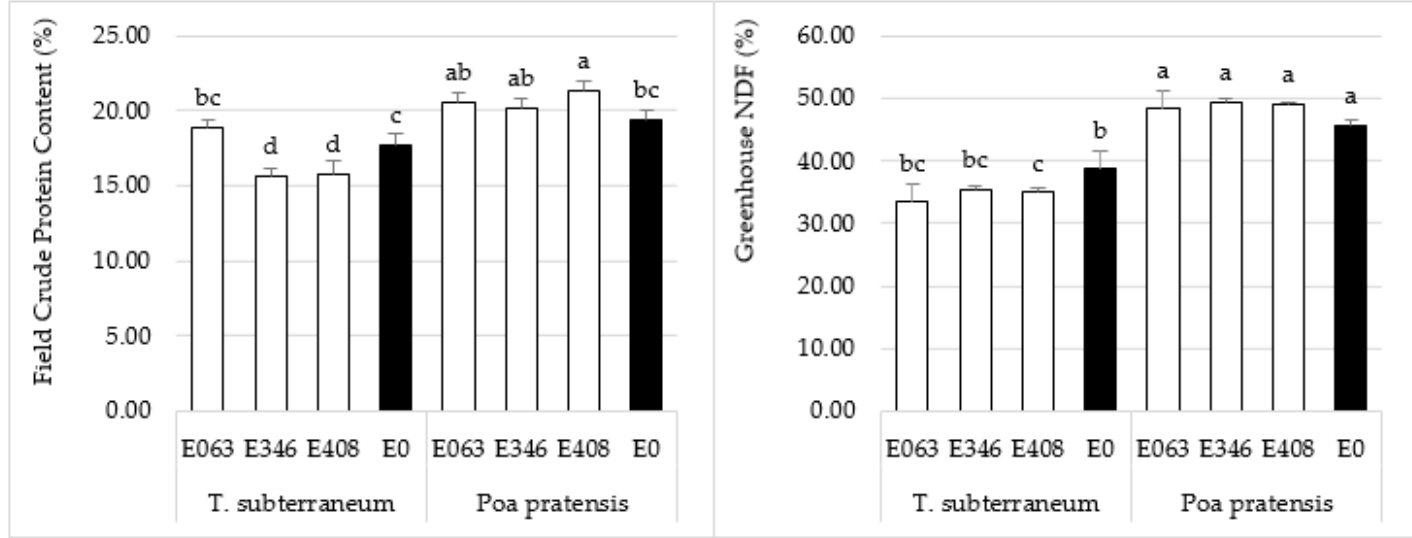

(a)

(b)
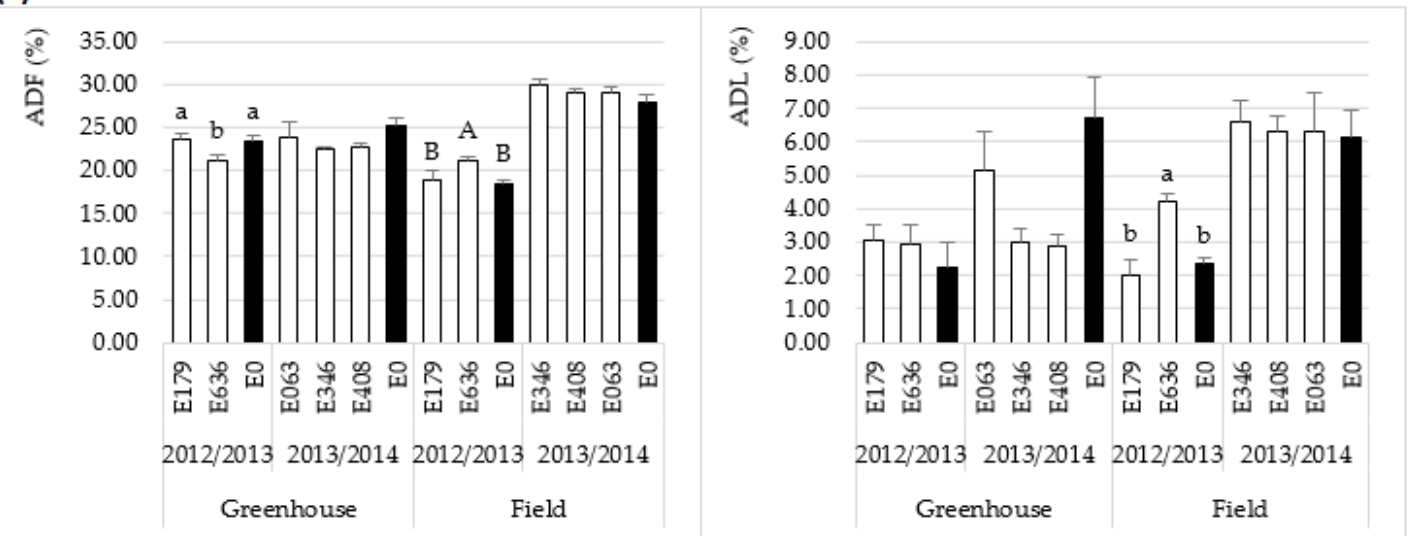

(C)

(D)

\section{Figure 3}

Effect of the interaction between endophyte inoculation and plant host on a) crude protein (CP) in the field experiment in 2013/2014; b) neutral detergent fibre (NDF) in the greenhouse in 2013/2014 (untransformed data for this parameter is shown). Effect of the endophyte inoculation on c) acid detergent fibre (ADF) and d) acid detergent lignin (ADL) in the greenhouse and field experiments in both study years. Vertical charts indicate means $(n=3)$ and error bars standard errors. For each parameter and year, different letters were assigned when significant differences were found according to LSD test $(p \leq 0.05)$. In order to make the differences clearer, a distinct set of letters (lowercase, uppercase and Greek letters) was assigned to each parameter. E0 (control), E063 (Mucor hiemalis), E179 (Epicoccum nigrum), E346 (Fusarium equiseti), E408 (Byssochlamys spectabilis) and E636 (Sporormiella intermedia).

\section{Supplementary Files}

This is a list of supplementary files associated with this preprint. Click to download.

- AppendixA.docx 